Canadian

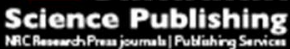

Canadian Geotechnical Journal Revue canadienne de géotechnique

\title{
MEANDER MIGRATION: THE OBSERVATION METHOD
}

\begin{tabular}{|r|l|}
\hline Journal: & Canadian Geotechnical Journal \\
\hline Manuscript ID & cgj-2015-0639.R1 \\
\hline Manuscript Type: & Article \\
\hline Date Submitted by the Author: & 28-Dec-2016 \\
\hline Complete List of Authors: & $\begin{array}{l}\text { Briaud, Jean-Louis; Texas A\&M University, Civil Engineering } \\
\text { Montalvo-Bartolomei, Axel; USACOE-ERDC, Geotechnical engineering }\end{array}$ \\
\hline Keyword: & \\
\hline \multicolumn{2}{|r}{} \\
\hline
\end{tabular}

SCHOLARONE ${ }^{\text {M }}$

Manuscripts 


\title{
MEANDER MIGRATION: THE OBSERVATION METHOD
}

\author{
Jean-Louis Briaud ${ }^{1}$, Axel M. Montalvo-Bartolomei ${ }^{2}$
}

\begin{abstract}
River meanders migrate over time and the consequences of this migration can create a problem for bridges and embankments near the river. This is why it is important to predict the lateral extent of future migration over the life of neighboring infrastructure. In the observation method for meander migration (OMM), the past movement and velocity history of the meander are used to back-calculate site specific erosion parameters. Those parameters serve as input to predict the meander migration for a chosen future velocity hydrograph. In this article and after a review of existing knowledge, the analytical steps leading to the development of the OMM are described, then the field and laboratory work at 4 full scale meander migration case histories are presented, and then the 4 full scale meander migration case histories are used to evaluate the OMM. The OMM has been automated in an Excel spreadsheet.
\end{abstract}

Keywords: Meander, migration, erosion, soil, case histories, observations, prediction

\section{INTRODUCTION}

River meanders migrate over time in a very complex fashion (Fig.1). The consequences of this migration can create a problem for bridges and embankments near the river. This is why it is important to predict the lateral extent of future migration over the life of neighboring

1. Professor and Holder of the Buchanan Chair, Zachry Dpt. of Civil Engineering, Texas A\&M University, College Station, Texas 77843-3136, USA (briaud@tamu.edu)

2. Professional Engineer, Geotechnical Engineering and Geosciences Branch, US Army Corps of Engineers, Engineer Research and Development Center, Vicksburg, MS, USA. 
infrastructure. In this paper, the observation method is used to develop a site specific meander migration prediction. The past movement of the meander and the past flow hydrograph at the meander site are used along with the flow of a chosen future flood such as the 100 year flood to predict the future movement. More precisely, a point is selected on the meander as well as a direction along which the movement is to be predicted. Past records of flow at the site and associated meander migration movement of the selected point are collected. Soil samples are tested for erosion resistance and the test results are used together with the observations to calibrate a site specific prediction model for the meander point. A future flood is selected and the future movement of the selected point is predicted. In the next sections, a background on meander migration is presented.

\section{EXISTING KNOWLEDGE ON MEANDER BEHAVIOR}

Many engineers have performed basic and applied research on the migration of meanders. The topics include theoretical studies on the flow pattern in bends, experiments in the laboratory to study the evolution of meanders, numerical modelling by computational fluid dynamics of the flow in the meander, field instrumentation and observations, and prediction models and methods. The papers on bend theory of erodible banks by Ikeda et al. (1981) further developed by Johannesson and Parker (1989) are part of the early work on this topic. Many laboratory experiments have also been conducted such as Blankaert and Graf (2001), Abad and Garcia (2009), Braudrick et al. (2009), and van Dijk et al. (2012). Papanicolaou et al. (2007) showed through numerical modelling that, due to secondary currents, the hydraulic shear stress on the outer bank can be 2 to 5 times larger than the depth average side wall shear stress. In 2011, Parker et al. proposed a new model with separate equations for the eroding bank and the 
deposition bank. Eke et al. (2014) performed numerical modelling to simulate both erosion and deposition while treating both banks independently. Motta et al. (2014) included the variation of the soil within the eroded zone in their numerical simulations. From the phenomenological point of view, the migration of a meander takes place by erosion of the outside bank and deposition of the eroded material on the inside bank (Fig. 2). This is due to the helical flow of the water at flood stage generated by the curve of the meander. Such helical flow and associated more complex phenomena have been experimentally measured by many investigators such as Blankaert and De Vriend (2004, 2005), and Abad and Garcia (2009). They also have been reproduced numerically using computational fluid dynamics codes such as Yeh (2008) and Briaud et al. (2007). This flow leads to a river cross section with a steep cliff on the outer bank and a gentle slope on the inner bank (Fig. 3). The erosion of the outside bank is often a combination of under cutting of the steep cliff because the hydraulic shear stress is highest at the bottom of the cliff, followed by sloughing of the overhang into the river, followed by erosiondisintegration of the sloughed soil chunks which are carried to the inner bank by the cross current component of the helical flow. That eroded soil is deposited on the inner bank because the velocity is lowest at that location. The deposited soil is the one with the heaviest particles (sand) because they settle down while finer particles are carried away for many more kilometers if not all the way to a sea or a lake. The rate of lateral erosion of the outer bank depends on the soil erodibility, on the water velocity, and on the mean radius of curvature of the meander. The water velocity and the radius of curvature of the meander control the imposed hydraulic shear stress while the soil erodibility controls the resisting shear stress or shear strength. This soil shear strength is measured in Pascals but the erosion process can be significantly affected by the amount and type of vegetation on the bank and any obstacle which slows the flow down at the 
interface between the soil and the water. The next sections are a review of some existing methods to predict meander migration.

\section{EXISTING KNOWLEDGE ON MEANDER MOVEMENT PREDICTION}

There are many methods available to predict meander migration; they can be classified into three main categories: database and regression analysis methods, fundamental modelling methods, and time sequence maps and extrapolation methods.

The database and regression analysis methods include Keady and Priest (1977) method, Hooke (1980) method, Brice (1982) method, and Nanson and Hickin (1983) method. Brice method is particularly simple as it gives the average meander migration rate as:

$$
\dot{M}_{r}=0.01 \mathrm{~b}
$$

where $\dot{M}_{r}$ is the meander migration rate (m/yr), and $\mathrm{b}$ is the channel width $(\mathrm{m})$. Nanson and Hickin (1983) identified an interesting behavior of meanders by collecting meander migration data for 18 rivers in Western Canada (Fig. 4). They proposed envelope curves shown as dashed lines on Fig. 4.

$$
\begin{gathered}
\dot{M}_{r} / \mathrm{b}=0.1\left(\left(\mathrm{r}_{\mathrm{c}} / \mathrm{b}\right)-1\right) \quad \text { when } \mathrm{r}_{\mathrm{c}} / \mathrm{b} \text { is smaller than } 2.3 \\
\dot{M}_{r} / \mathrm{b}=0.35\left(\mathrm{r}_{\mathrm{c}} / \mathrm{b}\right)^{-1} \quad \text { when } \mathrm{r}_{\mathrm{c}} / \mathrm{b} \text { is larger than } 2.3
\end{gathered}
$$

where $\dot{M}_{r}$ is the meander migration rate $(\mathrm{m} / \mathrm{yr}), \mathrm{b}$ is the channel width $(\mathrm{m})$, and $\mathrm{r}_{\mathrm{c}}$ is the radius of curvature of the meander (m). Nanson and Hickin (1983) observed that for a low radius of curvature to width ratios the migration rate is small and the river tends to straighten, that for large radius of curvature to width ratio the migration is again small as the centrifugal force in the 
water is small because of the large $r_{c}$ value and does not lead to significant erosion, but that for a radius of curvature to width ratio between 2 and 3 the migration rate is most severe (Fig. 4). This suggests a resonance phenomenon between the lateral flow of the water and the shape of the river channel as mentioned by Blondeaux and Seminara (1985).

The fundamental modelling methods to predict the migration of a meander include the methods proposed by Nagata et al. (2000), Darby et al. (2002), Duan and Julien (2005), Abad and Garcia (2006), Briaud et al. (2007). Some of the programs developed to predict meander migration are RVR MANDER (Abad, Garcia, 2006, Motta et al., 2012a), CONCEPT (Sutarto et al., 2014), and TAMU-MEANDER (Briaud et al., 2007). The CONCEPT program was expanded by Motta et al., (2012b) to consider the random spatial variation of the soil resistance. The input to TAMUMEANDER includes the three components of any erosion prediction process: geometry of the phenomenon, soil erodibility, water velocity and predicts the new location of the river. The work performed to develop TAMU-MEANDER was later abandoned in favor of the new Observation Method for Meander called TAMU-OMM proposed in this article.

The time sequence maps and extrapolation methods include Brice (1983) and Lagasse et al. (2004 a and b). Fig. 5 shows a sketch describing how the time sequence maps and extrapolation method is used. In a first step, a map of the meander is obtained for a first date $t_{1}$. A first best-fit circle is drawn to match as much of the $t_{1}$ dated meander shape as possible. The location of the center, $\mathrm{C}_{1}$, and the radius $\mathrm{R}_{1}$ of that first circle are recorded (Fig. 5). Then a map of the meander is obtained for a second date $t_{2}$, more recent than the first date $t_{1}$. Again a second best-fit circle is drawn to match as much of the $t_{2}$ dated meander shape as possible. The location of the center, $\mathrm{C}_{2}$, and the radius $\mathrm{R}_{2}$ of that second circle are recorded (Fig. 5). A linear extrapolation is used to predict the position of the meander at a future date $t_{3}$. This method has the significant advantage 
of making use of the actual behavior of the meander. It does have the weakness of assuming that the migration rate is constant over time regardless of the flow hydrograph. Observations made in the study described next show that meander migration proceeds by large migration during a few major events rather than an average movement over time. This was the impetus for developing the method described in this article (Montalvo-Bartolomei 2014).

\section{EROSION FUNCTION APPARATUS AND SOIL ERODIBILITY CLASSIFICATION}

A brief review of the EFA (Fig. 6) and associated soil erodibility classification (Fig. 7) is presented here because it is a critical part of the proposed method. The EFA (Briaud 2013) is used to quantify the erodibility of a soil. A soil sample is collected using a $76 \mathrm{~mm}$ diameter ASTM Standard thin wall steel tube pushed into the soil. The open steel tube is brought back to the laboratory where it is place through the bottom of a rectangular cross section conduit. A piston at the bottom of the sample pushes the sample out of the tube only as fast as it is eroded by the water flowing over it. The rate of movement of the piston is the erosion rate and the velocity of the water is measured by a flow meter. The relationship between the erosion rate and the water velocity or better hydraulic interface shear stress is the erosion function which characterizes the erodibility of the soil tested. Based on many EFA tests on a series of various soils, Briaud (2013) proposed an erosion category chart (Fig. 7) and indicated the likely soil classification associated with each erosion category. For the meander observation method, the erosion function of the soil along the meander bend is either measured directly in the EFA or estimated based on soil classification tests by the erosion chart. 


\section{THE OBSERVATION METHOD FOR MEANDER MIGRATION}

The observation method for meander or OMM aims at predicting the movement of a point that would occur during a chosen future flood (Fig. 8). The point considered is on the outside bank and the direction of the movement is selected to match the concerns associated with the engineering problem at hand. This direction may or may not be perpendicular to the main flow line of the river. The method works in the following simple steps.

1. Obtain the flow history at the meander site: flow Q vs time $t$ (Fig. 9).

2. Convert the flow history into velocity history at the meander site: velocity v vs. time $t$ (Fig. 10).

3. Select a point $\mathrm{M}$ on the outside bank of the meander and a direction along which the future position of point $\mathrm{M}$ is to be predicted (Fig. 8); obtain the meander migration history at the site along that direction from historical maps: migration distance $\mathrm{M}$ vs. time t (Fig. 11).

4. Obtain the erosion function for the soil at the site: erosion rate $\dot{z}$ vs. velocity v (Fig. 7).

5. Transform the soil erosion function of step 4 into the meander erosion function: meander migration rate $\dot{M}$ vs. velocity v. This is automated by using the TAMU-OMM spread sheet.

6. Consider a future flood with a velocity $v_{\text {fut }}$ sustained over a period of time $t_{\text {fut }}$ and calculate the movement of point $\mathrm{M}$ called meander migration $\mathrm{M}_{\text {fut }}$ during the future flood by using the meander erosion function of step 5 .

Each one of those steps is discussed in more details in the following paragraphs.

Step 1: Obtain the flow history at the meander site (Fig. 9) 
The ideal situation is to find a flow gage station at the meander site (e.g.: Water Office in Canada or USGS in the USA). If a flow gage is not available at the site, the nearest flow gage upstream or downstream on the same river is found and a flow correction based on the drainage basin area is applied.

$$
Q_{2}=Q_{1} \frac{A_{2}}{A_{1}}
$$

Where $\mathrm{Q}_{2}$ and $\mathrm{Q}_{1}$ are the flow rates at the meander site and at the USGS gage location respectively, and $A_{2}$ and $A_{1}$ are the drainage areas associated with the location of the meander site and the flow gage respectively.

\section{Step 2: Convert the flow history into velocity history (Fig. 9, 10)}

The conversion is based on the conservation of mass equation, $\mathrm{Q}=\mathrm{vA}$, where $\mathrm{Q}$ is the flow, $\mathrm{v}$ is the velocity, and $\mathrm{A}$ is the cross section area. The problem is that in open channel flow, the cross section area is not fixed and depends on many factors such as the slope and roughness of the river bottom. These factors are incorporated in software packages such as HEC-RAS (Brunner 2010) or more simply TAMU-FLOW (2010) which give the relationship between the flow Q and the velocity $\mathrm{v}$ for various water depths in the open channel.

Step 3: Choose migration direction and obtain the meander migration history (Fig. 8, 11)

This process is based on the collection of maps and aerial photos taken at different times during the movement of the meander. Such photos can be obtained from various sources including Google Earth (from 1990 to present) (https://www.google.com/earth/), Terraserver (http://www.terraserver.com/), USGS (http://www.usgs.gov/pubprod/aerial.html). Use an overlay technique to prepare a sequence of maps and/or aerial photos, select the migration direction or 
line of interest which may or may not be perpendicular to the main flow line of the river (Fig. 8), and plot the points of observed meander migration vs. time along that line (square dots on Fig. 11). The river bank line that should be used for this process is the outer bank line of the river.

Step 4: Obtain the erosion function for the soil (Fig. 6, 7)

This step can be achieved in one of two ways: measure the erosion function by EFA testing (Briaud 2013, Fig. 6) on samples from the site or estimate the erosion function using soil classification (Fig. 7). While the first option should be favored, the second option is more easily achievable though less site specific and less precise. The second option consists of performing classification tests (grain size analysis and Atterberg limits), classifying the soil of the outer bend of the meander according to the Unified Soil Classification System and then using Fig. 7. Given the USCS dual symbol, the erosion category (I through VI) is selected and the average or lower bound erosion function is chosen to represent the soil erodibility. Because it is a straight line on this log-log plot the expression of the erosion function is:

$$
\dot{\mathrm{z}}=\alpha \mathrm{v}^{\beta}
$$

Where $\dot{z}$ is the erosion rate, $v$ the mean depth velocity, $\alpha$ and $\beta$ soil parameters corresponding to the line on the erosion chart. It is preferable to present the erosion function in a normalized fashion as

$$
\frac{\dot{\mathrm{z}}}{\mathrm{v}_{\mathrm{c}}}=\alpha^{\prime}\left(\frac{\mathrm{v}}{\mathrm{v}_{\mathrm{c}}}\right)^{\beta}
$$

Where $\mathrm{v}_{\mathrm{c}}$ is the critical velocity defined as the velocity corresponding to a very low erosion rate chosen arbitrarily for this work as $0.1 \mathrm{~mm} / \mathrm{hr}$, and $\alpha^{\prime}$ is obtained from 


$$
\alpha^{\prime}=\frac{\dot{z}_{c(0.1)}}{v_{c}}
$$

Where $\mathrm{v}_{\mathrm{c}}$ is the critical velocity from the EFA curve and $\dot{\mathrm{z}}_{\mathrm{c}(0.1)}$ is the erosion rate at the critical velocity arbitrarily chosen as $0.1 \mathrm{~mm} / \mathrm{hr}$ or $2.78 \times 10^{-8} \mathrm{~m} / \mathrm{s}$. It has been shown (Perri et al. 2010) that the critical shear stress imposed on the soil by a small scale testing apparatus such as the EFA, can be significantly larger than the critical shear stress imposed on the soil in rivers. Many factors contribute to this difference including vegetation, water depth, geometry, compaction, countermeasures. This is why the site specific critical velocity must be obtained by calibration against the meander migration observations rather than taken directly from the result of EFA tests before Eq. 6 can be used to predict the future meander migration. The use of the EFA is to obtain the slope $\beta$ of the erosion function as explained in the following step 5.

\section{Step 5: Obtain the meander erosion function for the site}

The erosion function of the soil in the meander outer bank along the chosen direction is defined as the migration rate of the outer bank of the meander along that direction as a function of the mean flow velocity in the river meander. As pointed out in the existing knowledge section of this paper, the velocity in the neighborhood of the outer bank is typically higher than the mean flow velocity in the river meander. However the mean depth velocity is chosen here for simplicity purposes; this simplification induces some error in the prediction which is evaluated by comparing predicted versus measured meander migration at the end of the paper. As explained in step 4, the erosion function of the outer bank of the meander is not the same as the erosion function of the barren soil; this is due, for example, to the presence of vegetation or countermeasures and is particularly true for the critical velocity. Finding the true site specific critical velocity for the meander $\mathrm{v}_{\mathrm{cFIELD}}$ is done by matching, through an automated trial and 
error process, the observed meander migration distance over time. This optimization is described later. During this automated process, the meander migration $\Delta \mathrm{M}$ for a given day is calculated by using Eq. 6 applied to the meander migration as follows.

$$
\Delta M=\alpha^{\prime}\left(\frac{v}{v_{c F I E L D}}\right)^{\beta} \times v_{c F I E L D} \times \Delta t
$$

Where $\alpha^{\prime}$ is a site specific parameter (to be determined), $\beta$ is the erosion exponent obtained in the EFA as explained later (Note that if EFA data is not available, the erosion chart of Fig. 7 can be used instead with the soil classification), $\mathrm{v}$ is the mean depth velocity in the meander obtained from the hydrograph for the day considered, $v_{\text {cFIELD }}$ is the site specific critical velocity for the meander (to be determined), and $\Delta \mathrm{t}$ is one day. By using the velocity given by the hydrograph day by day, the migration distance $\mathrm{M}$, sum of all previous daily migrations $\Delta \mathrm{M}$, can be predicted as a function of time $\mathrm{t}$ (Fig. 11). TAMU-OMM compares the magnitude of the predicted migration $\mathrm{M}_{\mathrm{p}}$ with the observed migration $\mathrm{M}_{\mathrm{o}}$ for each trial critical velocity $\mathrm{v}_{\text {cFIELD. }}$ In the case of Fig. 11, three predicted migration values would be compared to three observed migration values. The goodness of fit between predicted and observed migration for a chosen $v_{\text {cFIELD }}$ is evaluated by calculating a Ranking Index RI defined as (Briaud and Tucker 1988):

$$
R I=|\mu(a)|+\sigma(a)
$$

Where a is the logarithm of the ratio of the predicted meander migration $\mathrm{M}_{\mathrm{p}}$ over the observed meander migration $\mathrm{M}_{\mathrm{o}}, \mu$ is the mean value of all a values, and $\sigma$ the standard deviation of the a values. If $\mu$ is close to zero, $M_{p} / M_{o}$ is close to 1 and if $\sigma$ is close to zero, $M_{p} / M_{o}$ exhibits very little scatter. So, if both $\mu$ and $\sigma$ are close to zero then the ratio $\mathrm{M}_{\mathrm{p}} / \mathrm{M}_{\mathrm{o}}$ is close to one and the scatter is small which is the goal of the optimization process. This is why seeking an RI value as close to zero as possible helps to optimize the prediction process. This optimization is automated 
in the software TAMU-OMM by starting with a critical velocity of $0.01 \mathrm{~m} / \mathrm{s}$ and increasing that critical velocity in increments of $0.01 \mathrm{~m} / \mathrm{s}$ while calculating and recording a ranking index RI, defined later, until the minimum RI is found. As noted above, the parameter $\beta$ is assumed to be the same for the meander and for the barren soil tested in the EFA because once the erosion process has started, it is the soil which erodes away. However the critical velocity $\mathrm{v}_{\mathrm{cFIELD}}$ and the coefficient $\alpha^{\prime}$ which is related to $\mathrm{v}_{\mathrm{cFIELD}}$ through Eq. 12 are found through this optimization process. The best fit critical velocity $\mathrm{v}_{\mathrm{cFIELD}}$ is reached when the Ranking Index (RI) reaches a minimum value. An example of the match between predicted and measured migration is shown in Fig. 11 for a meander of the Brazos River. In this example, the optimum critical velocity $\mathrm{V}_{\text {cFIELD }}$ was found to be $0.83 \mathrm{~m} / \mathrm{s}$ and corresponded to a ranking index RI equal to 0.23 . A velocity of $0.80 \mathrm{~m} / \mathrm{s}$ gave an RI value of 0.51 while a velocity of $0.86 \mathrm{~m} / \mathrm{s}$ gave an RI value of 0.55 indicating that $0.83 \mathrm{~m} / \mathrm{s}$ corresponded to a minimum value of RI. The sensitivity of the meander migration prediction to the value of the critical velocity is shown in Fig. 12. In this figure, the predicted meander migration versus time is plotted for three critical velocities equal to $0.70,0.83$, and $0.90 \mathrm{~m} / \mathrm{s}$. As can be seen, the predictions are quite sensitive to the critical velocity.

Step 6: Predict the meander migration during the chosen future flood

Once the meander critical velocity $\mathrm{v}_{\mathrm{cFIELD}}$ is found along with its associated $\alpha$ ' coefficient (Step 5), the predicted meander migration $M$ vs. time $t$ graph is generated. The migration $M$ is calculated as the accumulation of the migration generated each day of the hydrograph. As such 
the equation for obtaining $\mathrm{M}$ is the one shown below where all parameters on the right hand side have been determined in step 5 .

$$
M=\sum_{i=1 \text { day }}^{n \text { days }} \alpha^{\prime}\left(\frac{v_{i}}{v_{\text {cFIELD }}}\right)^{\beta} \times v_{c F I E L D} \times \Delta t
$$

The resulting graph is in Fig. 13. Note that, in the hydrograph, any day where the velocity is less or equal to the critical velocity, the migration increment is zero. Eq. 10 can now be used to predict the future migration of the meander under a chosen future hydrograph. The user may choose the 100 year flood as a single velocity future hydrograph for example to evaluate the migration of the meander under such a future flood. The user can also choose a more complex future hydrograph. In both cases TAMU-OMM can be used to predict the migration.

\section{CASE HISTORIES FOR METHOD VERIFICATION}

Four case histories of meander migration were selected for the development and verification of the observation method for meander migration (OMM). The meander location is identified as the intersection of the river and a highway because often the interest in predicting meander migration is associated with the impact it may have on a nearby bridge crossing that river and/or an approach embankment. Table 1 gives some basic information on the case histories. Note that the TAMU-OMM also works for river bed vertical degradation (Montalvo 2014).

The investigation for each case history consisted of the following:

1. Finding a series of aerial photographs and maps to document the meander migration over time. Figs. 8 and 14 show the case of the Brazos River at Highway 105.

2. Obtaining the flow hydrograph over the corresponding period and transforming it into a velocity hydrograph. Figs. 9 and 10 show the data for the Brazos River at Highway 105. 
3. Conducting a field investigation to observe the meander in action and collect samples from the eroding bank. Figs. 3 and 15 show the case of the Brazos River at Highway $105)$

4. Testing of the samples in the EFA as well as establishing the index properties of the samples. Table 2 and Fig. 16 show the case of the Brazos River at Highway 105.

Once this information was collected for each case history, the observation method evaluation process proceeded as follows

1. The observed record for a case history was split into a first period and a second period. For the Brazos River for example the first period was 1995 to 2007 and the second period from 2007 to 2013.

2. The TAMU-OMM program was used to optimize the fit between predicted meander migration and observed meander migration during the first period. This lead among other parameters to the field critical velocity $\mathrm{v}_{\text {cFIELD }}$ (Table 3).

3. Using the optimized parameters from matching the meander migration during the first period, TAMU-OMM was used to predict the meander migration during the second period. The predicted meander movement of this second period is then compared with the last observed meander migration; this is possible because now the future is in the past.

The results of the matching process during the first period and the comparison between predicted and observed migration during the second period are shown in Figs. $17 \mathrm{a}$ and $\mathrm{b}$ to $20 \mathrm{a}$ and $\mathrm{b}$. Note that the field critical velocity $\mathrm{v}_{\mathrm{cFIELD}}$ was consistently much higher than the barren soil critical velocity measured in the EFA $\mathrm{v}_{\mathrm{cEFA}}$. The ratio $\mathrm{v}_{\mathrm{cFIELD}} / \mathrm{v}_{\mathrm{cEFA}}$ averaged 3.81 . This process provided an evaluation of the observation method for meander migration. The good results 
obtained and presented in Figs. 17 to 20 gave a certain level of confidence in the validity of the method.

\section{THE BIG EVENTS ARE CONTRIBUTING THE MOST}

One of the very important lessons learned from this study is that meander migration can occur by small increments through many small events or by large increments through a few major events. The Brazos River (Fig. 21) is a good example of a river which has limited variations in velocity. As a result the meander migrates fairly uniformly over time at a rate of $2 \mathrm{~m} / \mathrm{y}$. By comparison the Nueces River (Fig. 22) is a river with more extreme variations in velocity. As a result, the meander migrates by major increments some as large as $40 \mathrm{~m}$ in one event. Such an event nearly took out the right abutment of the Nueces River in 1998 and prompted the placement of emergency riprap. In that respect, rivers such as the Nueces River are more dangerous because more unpredictable than the rivers such as the Brazos River. Note that TAMU-OMM is able to reproduce the two types of processes.

\section{COMPARISON WITH OTHER METHODS}

A comparison was made with some of the meander migration methods for which the data was available to make the prediction (Fig. 23). This included the Brice (1982) method and the Nanson and Hickin (1983) method. These two methods predict a constant rate of migration per year so the prediction versus time is a straight line. The predicted rate for the Brice method was $1.04 \mathrm{~m} / \mathrm{yr}$ and for the Nanson and Hickin method $8.62 \mathrm{~m} / \mathrm{yr}$. Note that the radius of curvature 
needed in the Nanson and Hickin method introduces some uncertainty as some judgement is needed to determine that radius.

\section{CONCLUSIONS}

The observation method for meander migration (OMM) is proposed to predict the future migration of meanders based on their past behavior. The OMM proceeds in steps as follows:

1. Collect aerial photos and maps to document the past movement of the meander. A period of about 20 years was used in this study.

2. Choose the point on the outer bank of the meander and the line along which the meander movement is of concern; plot the movement of that point along that line as a function of time during the period of observation.

3. Collect the flow hydrograph, from a USGS gage for example, corresponding to the period of observation.

4. Transform that flow hydrograph into a velocity hydrograph using HEC-RAS or TAMUFLOW.

5. Collect samples at the site and perform EFA tests to obtain the erosion function of the soil in the meander bank. If this is not possible, use the erosion chart and the soil classification to select an erosion function for that soil.

6. Use the TAMU-OMM spread sheet (Montalvo Bartolomei 2014), which is available from the authors, together with the erosion function and the velocity hydrograph as input to match the observed movement of the point on the meander during the period of 
observation. This gives the best parameters for the prediction of future meander migration including the critical velocity in the field.

7. Use the back calculated parameters of step 6 and a chosen future velocity hydrograph to predict the future migration of the same point in the meander along the chosen direction.

The OMM was developed and verified on 4 full scale meander case histories. The results are very encouraging. The limitations of the OMM are that it requires good records of past meander movement, availability of a flow hydrograph, collection and testing of soil samples from the river bank. The OMM also assumes that the soil to be eroded in the future will be similar to the soil which has been eroded during the period of observation. The OMM has several advantages as it is based on the actual soil at the site and the actual geometry of the meander; it also takes into account the velocity history rather than relying on averages over time. It is able to predict the movement of meanders whether the river has steady regular events or a few isolated extreme events. It is also able to predict the future movement under a selected recurrence interval storm such as the 100 year storm. The OMM is also capable of predicting the vertical degradation of a river bed (Montalvo, 2014).

\section{ACKNOWLEDGEMENTS}

This work was funded by the Texas Dpt. of Transportation through the University of Texas at San Antonio. At TxDOT, the contact was Mr. Daniel Richardson while at UTSA the contact was Dr Xiaofeng Liu. We appreciate the support and help of both organizations. 


\section{REFERENCES}

Abad, J.D., and Garcia, M.H. 2006, "RVR Meander: A toolbox for re-meandering of channelized streams”, Journal of Computers \& Geosciences, Volume 32 Issue 1, February, 2006, pp 92-101, Pergamon Press, Inc. Tarrytown, NY, USA

Abad, J. D., and Garcia, M.H. 2009. "Experiments in a high-amplitude Kinoshita meandering channel”, Water Resources Research, Vol. 45, W02401, American Geophysical Union.

Blanckaert, K., and H. J. de Vriend, H.J. 2004. "Secondary flow in sharp open- channel bends", J. Fluid Mech., Vol. 498, pp. 353-380, Cambridge University Press.

Blanckaert, K., and Graf, W.H. 2001. "Mean flow and turbulence in open- channel bend", J. Hydraul. Eng., Vol. 127, No. 10, pp. 835-847, American Society of Civil Engineers.

Blanckaert, K., and de Vriend, H.J. 2005. "Turbulence characteristics in sharp open-channel bends", Physics of Fluids, Vol. 17 No. 5, 055102, American Institute of Physics.

Blondeaux, P., and Seminara, G. 1985. "A unified bar-bend theory of river meanders", J. Fluid Mech., Vol. 157, pp. 449-470, Cambridge University Press.

Braudrick, C.A., Dietrich, W.E., Leverich, G.T., and Sklar, L.S. 2009. "Experimental evidence for the conditions necessary to sustain meandering in coarse-bedded rivers", Proceedings of the National Academy of Sciences of the United States of America, Vol. 106, No. 40, pp. 16936-16941.

Briaud, J.-L. 2013. "Geotechnical engineering: unsaturated and saturated soils", John Wiley and Sons publishers, New York, 1000 pages.

Briaud, J.-L., Chen, H.C., Chang, K.A., Chung, Y.-A., Park, N., Wang, W., and Yeh, P.-H. 2007. "Establish guidance for soil properties-based prediction of meander migration rate", Report 0-4378-1 by the Texas A\&M Transportation Institute to the Texas Department of 
Transportation, Report No. FHWA/TX-07/0-4378-1, Zachry Dept. of Civil Engineering, Texas A\&M Univ., College Station, Texas, USA..

Briaud, J.-L. 2008. "Case Histories in Soil and Rock Erosion: Woodrow Wilson Bridge, Brazos River Meander, Normandy Cliffs, and New Orleans Levees", The 9th Ralph B. Peck Lecture, Journal of Geotechnical and Geoenvironmental Engineering, Vol 134, No.10, ASCE, Reston Virginia, USA.

Briaud, J.L., and Tucker, L. M. 1988. "Measured and predicted axial response of 98 piles.” J. Geotech. Engrg., 114 (9), 984-1001.

Brice, J.C. 1982. "Stream Channel Stability Assessment," Report No. FHWA/RD-82/021, Federal Highway Administration, Washington, DC, USA, p.41.

Brice, J.D. 1983. "Factors in Stability of Relocated Channels," Journal of Hydraulic Engineering, ASCE, Vol. 109, No. 10, pp. 1298-1313.

Brunner, G.W. 2010. “HEC-RAS River Analysis System Hydraulic Reference Manual.” Version 4.1, Rep. No. CPD-69, U.S. Army Corps of Engineers, Institute for Water Resources, Hydrologic Engineering Research Center, Davis, Calif. 411 pp.

Darby, S.E., Alabyan, A.M., and Van de Wiel, M.J. 2002. "Numerical simulation of bank erosion and channel migration in meandering rivers", Water Resources Research, Volume 38, Issue 9, pages 2-1-2-21, September 2002 American Geophysical Union.

Duan, J.G., and Julien, P.Y. 2005. "Numerical simulation of the inception of channel meandering”, Issue Earth Surface Processes and Landforms, Special Issue: Quantifying Rates and Timescales of Geomorphic Processes: Part 2. Volume 30, Issue 9, pages 10931110, August 2005, John Wiley \& Sons, Ltd. 
Eke, E., Parker, G., and Shimizu, Y. 2014. "Numerical modeling of erosional and depositional bank processes in migrating river bends with self-formed width: morphodynamics of bar push and bank pull”, Journal of Geophysical Research: Earth Surface, Vol. 119, pp.14551483, American Geophysical Union.

Fisk, H. 1944. "Map of ancient courses of the Mississippi River, Cape Girardeau, MO Donaldsonville, LA. Plate 22-10”, US Army Corps of Engineers, Engineering Research and Development Center, http://lmvmapping.erdc.usace.army.mil/.

Hooke, J.M. 1980. "Magnitude and Distribution of Rates of River Bank Erosion, Earth Surface Processes, Vol. 5, No. 2, pp.143-157, John Wiley, Chichester, NY.

Ikeda, S., Parker, G., and Sawai, K. 1981. "Bend theory of river meanders. Part 1. Linear development”, J. Fluid Mech., Vol. 112, pp. 363-377, Cambridge University Press.

Johannesson, H., and Parker, G. 1989. "Secondary Flow in Mildly Sinuous Channel”, Journal of Hydraulic Engineering, Vol. 115, No. 3, pp. 289-308, American Society of Civil Engineers.

Keady, P.D., and Priest, M.S. 1977. "The Downstream Migration Rate of River Meandering Patterns," Proceedings, 12th Mississippi Water Resources Conference, Jackson, Mississippi, USA, pp.29-34.

Lagasse, P. F., Zevenbergen, L.W., Spitz, W. J., and Thorne, C.R. 2004a. "Methodology for predicting channel migration." NCHRP web only document 67 (Project 24-16), TRB Washington DC, USA.

Lagasse, P.F., Spitz, W.J., Zevenbergen, L.W., and ZachMann, D.W. 2004b. "Handbook for predicting stream meander migration", NCHRP report 533 (Project 24-16), TRB Washington DC, USA. 
Montalvo Bartolomei, A.M. 2014. "Observation method to predict meander migration and vertical degradation of rivers", Master of Science thesis, Zachry Dpt. of Civil Engineering, Texas A\&M University, College Station, Texas, USA, pp.153.

Motta, D., Abad, J.D., Langendoen, E.J., and Garcia, M.H. 2012a. “A simplified 2D model for meander migration with physically-based bank evolution”, Geomorphology 163-164, pp. 10-25, Elsevier.

Motta, D., Abad, J. D., Langendoen, E. J., and Garcia, M. H. 2012b. "The effects of floodplain soil heterogeneity on meander planform shape", Water Resources Research, Vol. 48, W09518, American Geophysical Union.

Motta, D., Langendoen, E. J., Abad, J.D., and García, M.H. 2014. "Modification of meander migration by bank failures", Journal of Geophysical Research: Earth Surface, Vol. 119, pp.1026-1042, American Geophysical Union.

Nagata, N., Hosoda, T., and Muramoto, Y. 2000. "Numerical Analysis of River Channel Processes with Bank Erosion.” J. Hydraul. Eng., Volume 126, Issue 4 (April 2000), pp. 243-252, American Society of Civil Engineers.

Nanson, G.C., and Hickin, E.J. 1986. “A statistical analysis of bank erosion and channel migration in western Canada", Geological Society of America Bulletin, v.97, p. 497-504.

Papanicolaou, A.N., Elhakeem, M., R., and Hilldale, R. 2007. "Secondary current effects on cohesive river bank erosion”, Water Resources Research, Vol. 43, W12418, American Geophysical Union.

Parker, G., Shimizu, Y., Wilkerson, G.V., Eke, E.C., Abad, J.D., Lauer, J.W., Paola,C., Dietrich, W.E., and Voller, V.R. 2011. "A new framework for modeling the migration of 
meandering rivers", Earth Surf. Process. Landforms Vol. 36, pp. 70-86, John Wiley \& Sons, Ltd.

Perri, J., Shewbridge, S., Millet, R., Huang, W., Vargas, J., Inamine, M., and Mahnke, S. 2010. “Site Factor for Use of Velocity-Based EFA Erosion Rates.” International Conference on Scour and Erosion (ICSE-5) 2010; November 7-10, 2010, San Francisco, California, United States, Proceedings, ASCE Geotechnical Special Publication (GSP) No. 210, Scour and Erosion, pp. \#172-181.

Sutarto, T., Papanicolaou A.N., Wilson C.G., and Langendoen, E.J. 2014. "Stability analysis of semicohesive streambanks with CONCEPTS: coupling field and laboratory investigations to quantify the onset of fluvial erosion and mass failure", Journal of Hydraulic Engineering, ASCE, ISSN 0733-9429/04014041(19).

TAMU-FLOW 2010. "A simple program to convert flow to velocity in open channels", https://ceprofs.tamu.edu/briaud/research_wip.html

van Dijk, W. M., van de Lageweg, W. I., and Kleinhans, M.G. 2012. "Experimental meandering river with chute cutoffs", Journal of Geophysical Research, Vol. 117, F03023, American Geophysical Union.

Yeh, P.-H. 2008. "Physical models of meander channel migration”, Ph.D. dissertation, Zachry Dpt. of Civil Engineering, Texas A\&M Univ., College Station, Texas, USA. 


\section{FIGURE CAPTIONS}

Fig. 1 - Mississippi Meanders (Fisk 1944 Map of ancient courses of the Mississippi River, Cape Girardeau, MO-Donaldsonville, LA. Plate 22-10.) http://lmvmapping.erdc.usace.army.mil/ Fig. 2 - Brazos River meander at Highway 105.

Fig. 3 - Movement of the Brazos River cross section (Briaud 2008) near the location in Fig. 2: (a) diagram to scale, (b) diagram not to scale, 10 vertical to 1 horizontal. (with permission of ASCE)

Fig. 4 - Migration rate vs. radius of curvature (after Nanson and Hickin 1983).

Fig. 5 - Definitions for the Time Sequence Maps and Extrapolation Method

Fig. 6 - Erosion Function Apparatus setup and test (Briaud 2013): (a) sketch of the test, (b) sketch of an erosion function, (c) the EFA

Fig. 7 - Soil erosion chart (Briaud 2013)

Fig. 8 - Migration of the Brazos River meander from 1995 to 2013.

Fig. 9 - Flow hydrograph for the Brazos River at the meander location from 1960 to 2013 (USGS gage station 8111500).

Fig. 10 - Velocity hydrograph for the Brazos River at the meander location from 1960 to 2013 (USGS gage station 8111500).

Fig. 11 - Meander migration of the Brazos River meander from 1995 to 2013.

Fig. 12 - Sensitivity of meander migration prediction to the critical velocity.

Fig. 13 - Predicted future meander migration.

Fig. 14 - Brazos River meander and sample locations (Courtesy of Google Maps): (a) map, (b) Aerial photo.

Fig. 15 - Collecting samples from the bank 
Fig. 16 - EFA tests results

Fig. 17 - Brazos River verification of prediction with field critical velocity of $0.83 \mathrm{~m} / \mathrm{s}$. (a) first matching period, (b) second prediction period.

Fig. 18 - Trinity River verification of prediction with field critical velocity of $0.77 \mathrm{~m} / \mathrm{s}$. (a) first matching period, (b) second prediction period.

Fig. 19 - Sabine River verification of prediction with field critical velocity of $0.91 \mathrm{~m} / \mathrm{s}$. (a) first matching period, (b) second prediction period.

Fig. 20 - Nueces River verification of prediction with field critical velocity of $0.54 \mathrm{~m} / \mathrm{s}$. (a) first matching period, (b) second prediction period.

Fig. 21 - Velocity hydrograph and corresponding meander migration for the Brazos River (critical field velocity $=\mathbf{0 . 8 3} \mathrm{m} / \mathrm{s}$ )

Fig. 22 - Velocity hydrograph and corresponding meander migration for the Nueces River (critical field velocity $=0.54 \mathrm{~m} / \mathrm{s}$ )

Fig. 23 - Comparison between the prediction by TAMU-OMM, Brice (1982) and Nanson and Hickin (1983). 
4 Tables and Figures are to appear in the printed version in black and white and on the web version 5 in color when they are in color.

6

7

8

\begin{tabular}{|c|c|c|c|c|}
\hline \multirow{2}{*}{ RIVER } & & & & NUMBER OF \\
& HIGHWAY & NEAREST & PERIOD OF & MEANDER \\
& & CITY & OBSERVATION & MIGRATION \\
\hline Brazos River & SH105 & Navasota, TX & $1995-2013$ & MEASUREMENTS \\
\hline Trinity River & FM157 & Cleveland, TX & $1971-1998$ & 4 \\
\hline Sabine River & SH63 & Texas-Louisiana & $1990-2013$ & 4 \\
\hline Nueces River & US90 & Uvalde, TX & $1969-2012$ & 4 \\
\hline
\end{tabular}

9

10

11

12

13

\section{MEANDER MIGRATION: THE OBSERVATION METHOD}

Jean-Louis Briaud $^{1}$, Axel M. Montalvo-Bartolomei ${ }^{2}$ 
4 Tables and Figures are to appear in the printed version in black and white and on the web version 5 in color when they are in color.

6

Table 2. Soil data at meander field site

\begin{tabular}{|c|c|c|c|c|c|c|}
\hline River & Sample & $\mathbf{N}$ & $\mathbf{W}$ & $\begin{array}{c}\text { Soil } \\
\text { Classification }\end{array}$ & $\begin{array}{l}\text { EFA critical } \\
\text { velocity } v_{\text {cEFA }}\end{array}$ & $\begin{array}{l}\text { Field critical } \\
\text { velocity } \\
\mathrm{v}_{\text {cFIELD }}\end{array}$ \\
\hline \multirow{4}{*}{ Brazos River } & S1B1 & $30^{\circ} 21^{\prime} 49.20^{\prime \prime} \mathrm{N}$ & $96^{\circ} 9^{\prime} 8.50^{\prime \prime} \mathrm{W}$ & SM & \multirow{4}{*}{$0.2 \mathrm{~m} / \mathrm{s}$} & \multirow{4}{*}{$0.83 \mathrm{~m} / \mathrm{s}$} \\
\hline & S1B4 & $30^{\circ} 21^{\prime} 47.50^{\prime \prime} \mathrm{N}$ & $96^{\circ} 9^{\prime} 12.10^{\prime \prime} \mathrm{W}$ & SM & & \\
\hline & S1B5 & $30^{\circ} 21^{\prime} 41.60^{\prime \prime} \mathrm{N}$ & $96^{\circ} 9^{\prime} 18.90^{\prime \prime} \mathrm{W}$ & SP-SM & & \\
\hline & S1B6 & $30^{\circ} 21^{\prime} 41.80^{\prime \prime} \mathrm{N}$ & $96^{\circ} 9^{\prime} 21.00^{\prime \prime} \mathrm{W}$ & $\mathrm{CL}$ & & \\
\hline \multirow{4}{*}{ Trinity River } & S2B1 & $30^{\circ} 25^{\prime} 42.70^{\prime \prime} \mathrm{N}$ & $94^{\circ} 50^{\prime} 50.30^{\prime \prime} \mathrm{W}$ & SM & \multirow{4}{*}{$0.2 \mathrm{~m} / \mathrm{s}$} & \multirow{4}{*}{$0.77 \mathrm{~m} / \mathrm{s}$} \\
\hline & S2B2 & $30^{\circ} 25^{\prime} 42.70^{\prime \prime} \mathrm{N}$ & $94^{\circ} 50^{\prime} 49.70^{\prime \prime} \mathrm{W}$ & SM & & \\
\hline & S2B4 & $30^{\circ} 25^{\prime} 29.61 " \mathrm{~N}$ & $94^{\circ} 51^{\prime} 4.69^{\prime \prime} \mathrm{W}$ & $\mathrm{SC}$ & & \\
\hline & S2B5 & $30^{\circ} 25^{\prime} 30.00^{\prime \prime} \mathrm{N}$ & $94^{\circ} 51^{\prime} 4.60^{\prime \prime} \mathrm{W}$ & SP & & \\
\hline \multirow{3}{*}{ SH 63 at Sabine } & S3B1 & $31^{\circ} 3^{\prime} 51.90^{\prime \prime} \mathrm{N}$ & $93^{\circ} 31^{\prime} 13.50^{\prime \prime} \mathrm{W}$ & SM & \multirow{3}{*}{$0.25 \mathrm{~m} / \mathrm{s}$} & \multirow{3}{*}{$0.91 \mathrm{~m} / \mathrm{s}$} \\
\hline & S3B2 & $31^{\circ} 3^{\prime} 52.14^{\prime \prime} \mathrm{N}$ & $93^{\circ} 31^{\prime} 13.02^{\prime \prime W}$ & SP & & \\
\hline & S3B3 & $31^{\circ} 3^{\prime} 51.96^{\prime \prime} \mathrm{N}$ & $93^{\circ} 31^{\prime} 12.12^{\prime \prime} \mathrm{W}$ & SM & & \\
\hline \multirow{4}{*}{ US 90 at Nueces } & S5B1 & $29^{\circ} 12^{\prime} 28.62^{\prime \prime} \mathrm{N}$ & $99^{\circ} 54^{\prime} 12.66^{\prime \prime W}$ & SP & \multirow{4}{*}{$0.15 \mathrm{~m} / \mathrm{s}$} & \multirow{4}{*}{$0.54 \mathrm{~m} / \mathrm{s}$} \\
\hline & S5B2 & $29^{\circ} 12^{\prime} 29.10^{\prime \prime} \mathrm{N}$ & $99^{\circ} 54^{\prime} 12.54^{\prime \prime W}$ & SM & & \\
\hline & S5B3 & $29^{\circ} 12^{\prime} 32.70^{\prime \prime} \mathrm{N}$ & $99^{\circ} 54^{\prime} 10.50^{\prime \prime} \mathrm{W}$ & SM & & \\
\hline & S5B7 & $29^{\circ} 12^{\prime} 39.30^{\prime \prime} \mathrm{N}$ & 9953'53.34"W & SM & & \\
\hline
\end{tabular}




\section{MEANDER MIGRATION: THE OBSERVATION METHOD}

4 Tables and Figures are to appear in the printed version in black and white and on the web version

5 in color when they are in color.

6

\begin{tabular}{|c|c|}
\hline$\alpha^{\prime}$ & $3.35 \times 10^{-8}$ \\
\hline$\beta$ & 8.58 \\
\hline $\mathrm{V}_{\mathrm{cFIELD}}$ & $0.83 \mathrm{~m} / \mathrm{s}$ \\
\hline $\mathrm{RI}$ & 0.341770 \\
\hline
\end{tabular}

12

13 


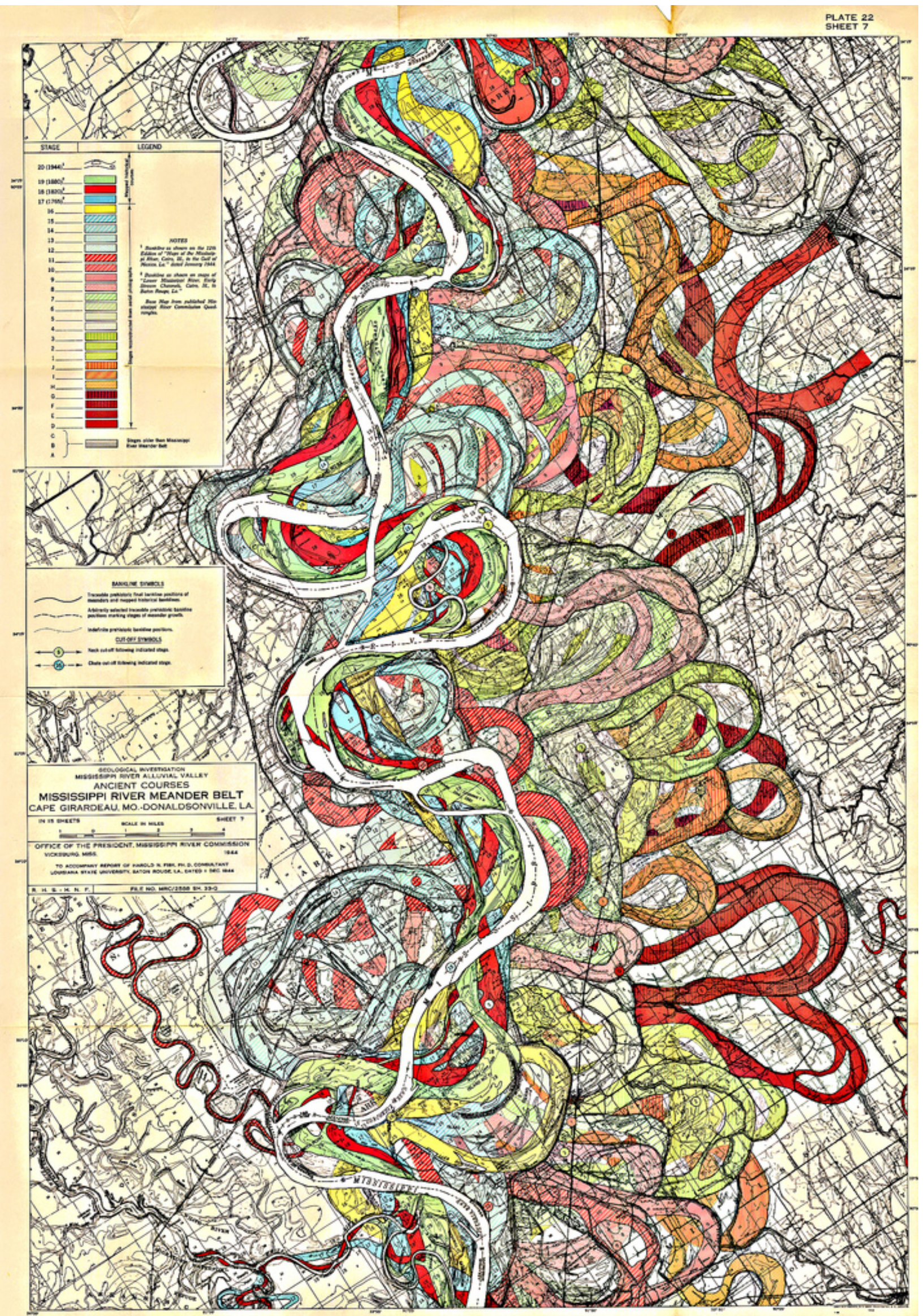

https://mc06.manuscriptcentral.com/cgj-pubs

Figure 1 - Mississippi Meanders (Fisk, 1944, Map of ancient courses of the Mississippi River, Cape Girardeau, MO-Donaldsonville, LA. Plate 22-10.) http://lmvmapping.erdc.usace.army.mil/ 


\section{Undercutting}

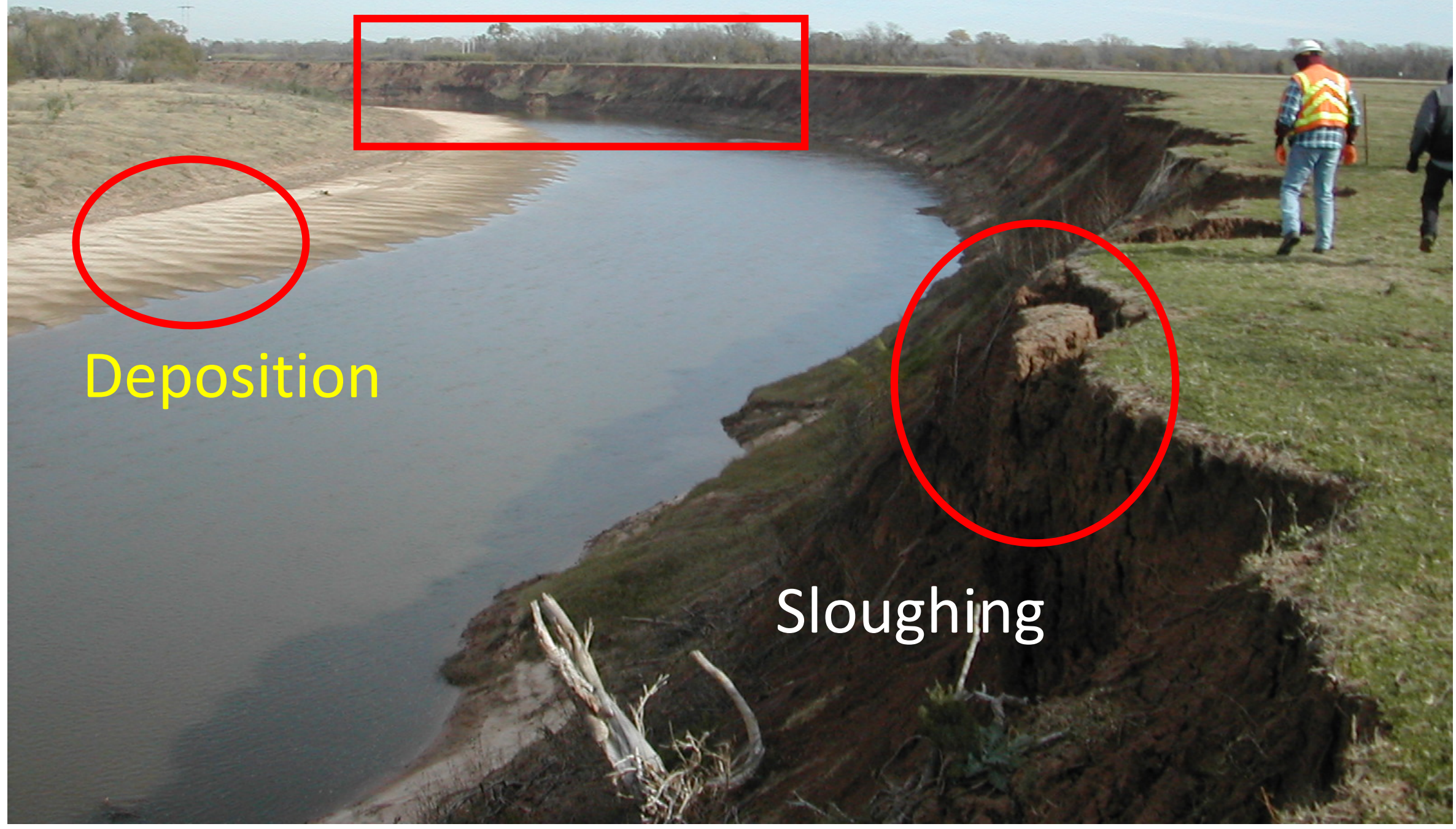

Figure 2 - Brazos River meander at Highway 105 . 

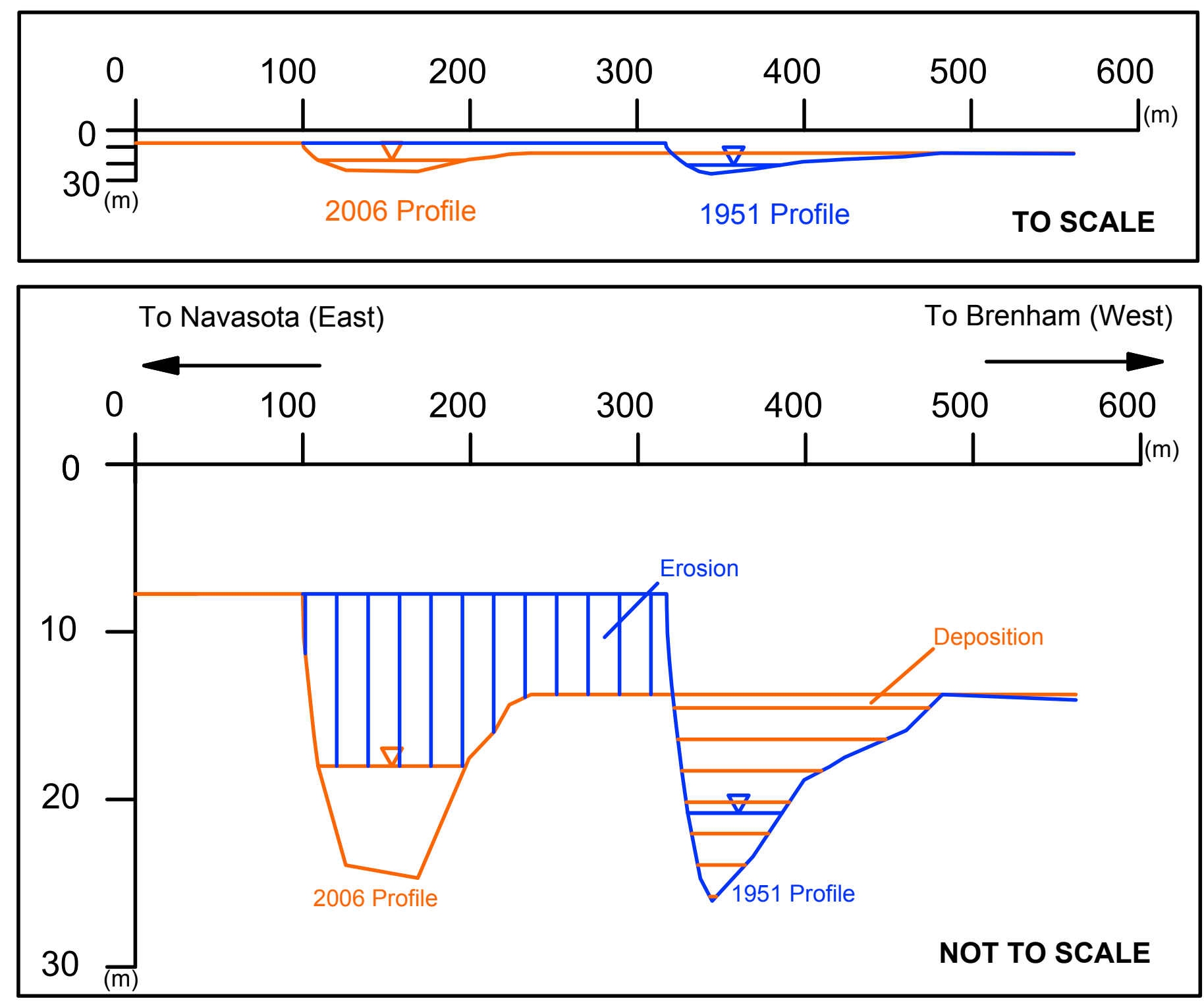

https://mc06.manuscriptcentral.com/cgj-pubs
Fig. 3 - Movement of the Brazos River cross section (Briaud, 2008) near the location in Fig. 2: (a) diagram to scale, (b) diagram not to scale, 10 vertical to 1 horizontal. 

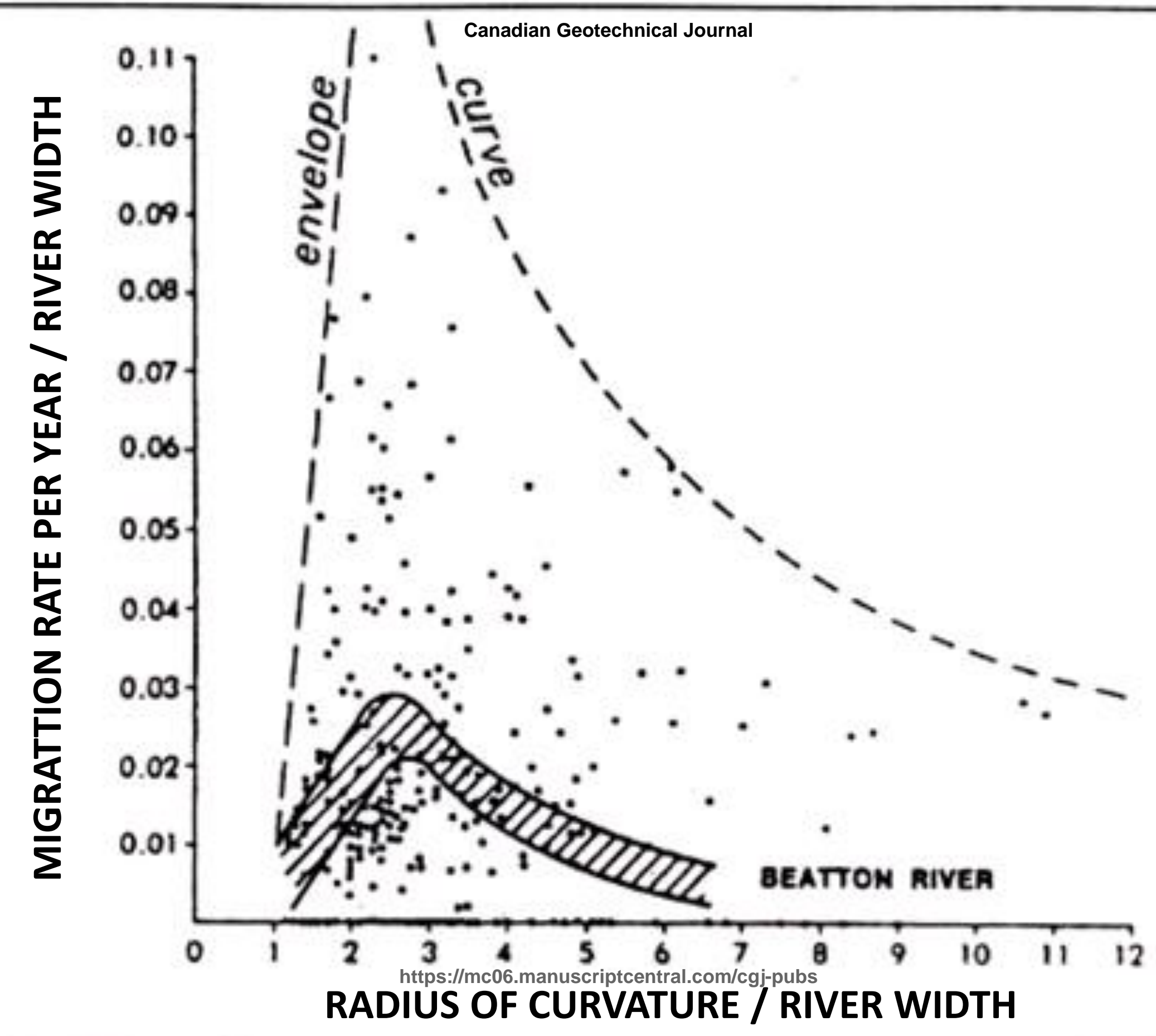


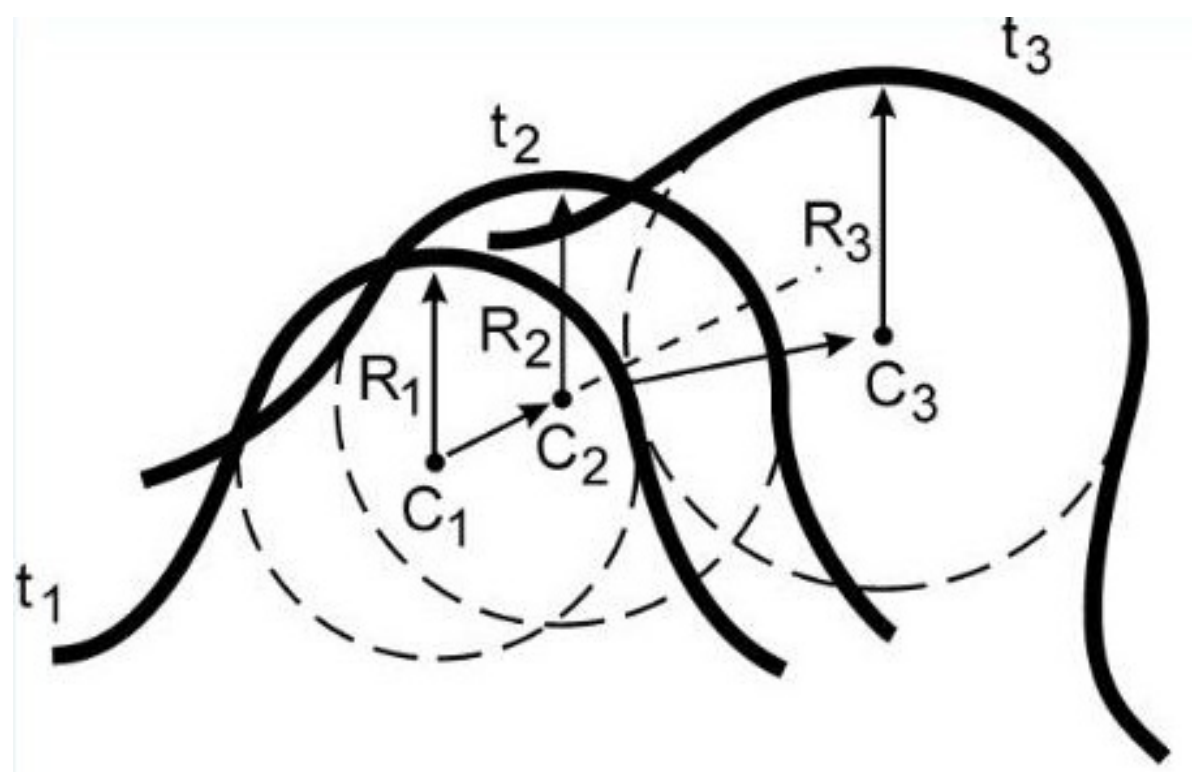

(a)

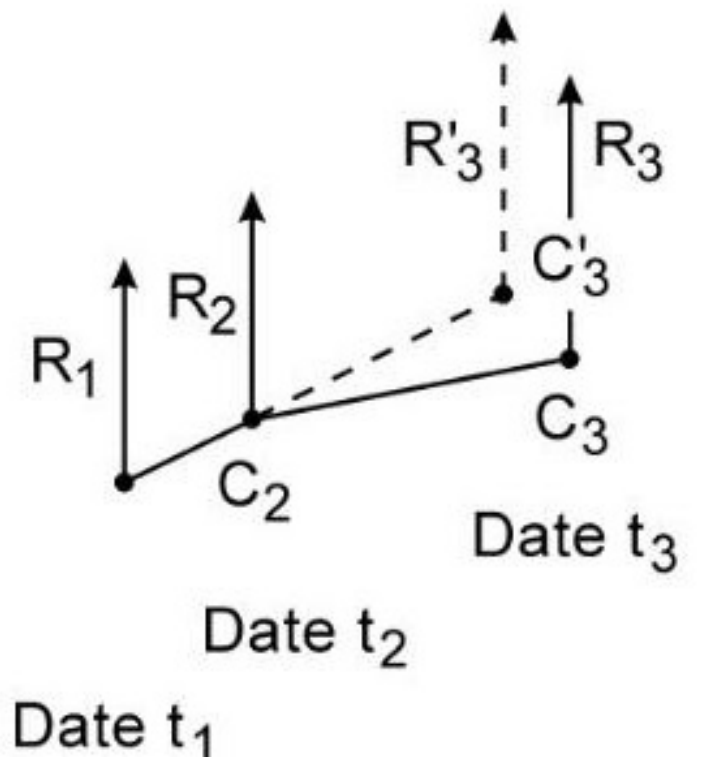

(b)

Fig. 5 - Definitions for the Time Sequence Maps and Extrapolation Method 


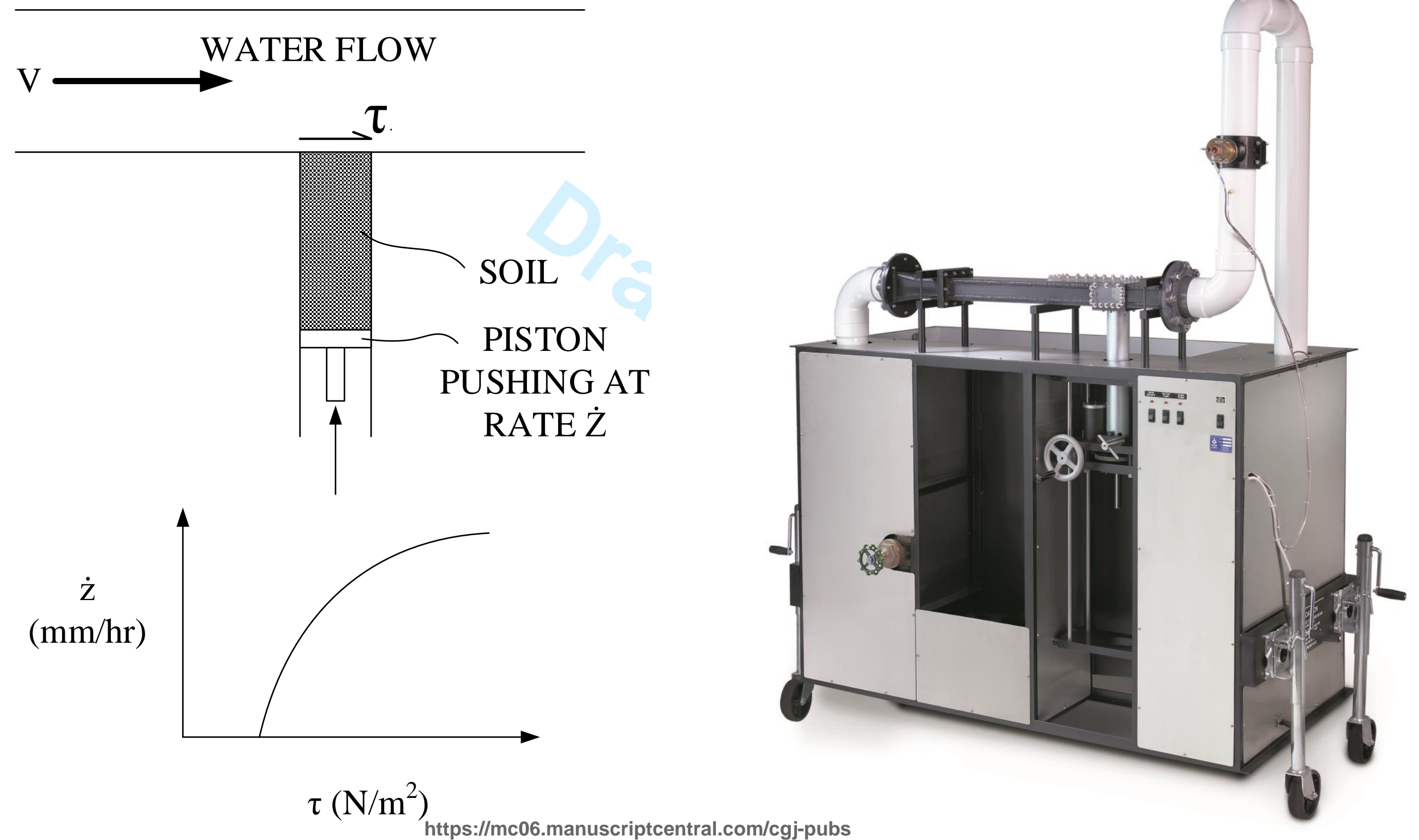

Fig. 6 - Erosion Function Apparatus setup and test (Briaud, 2013): (a) sketch of the test, (b) sketch of an erosion function, (c) the EFA 


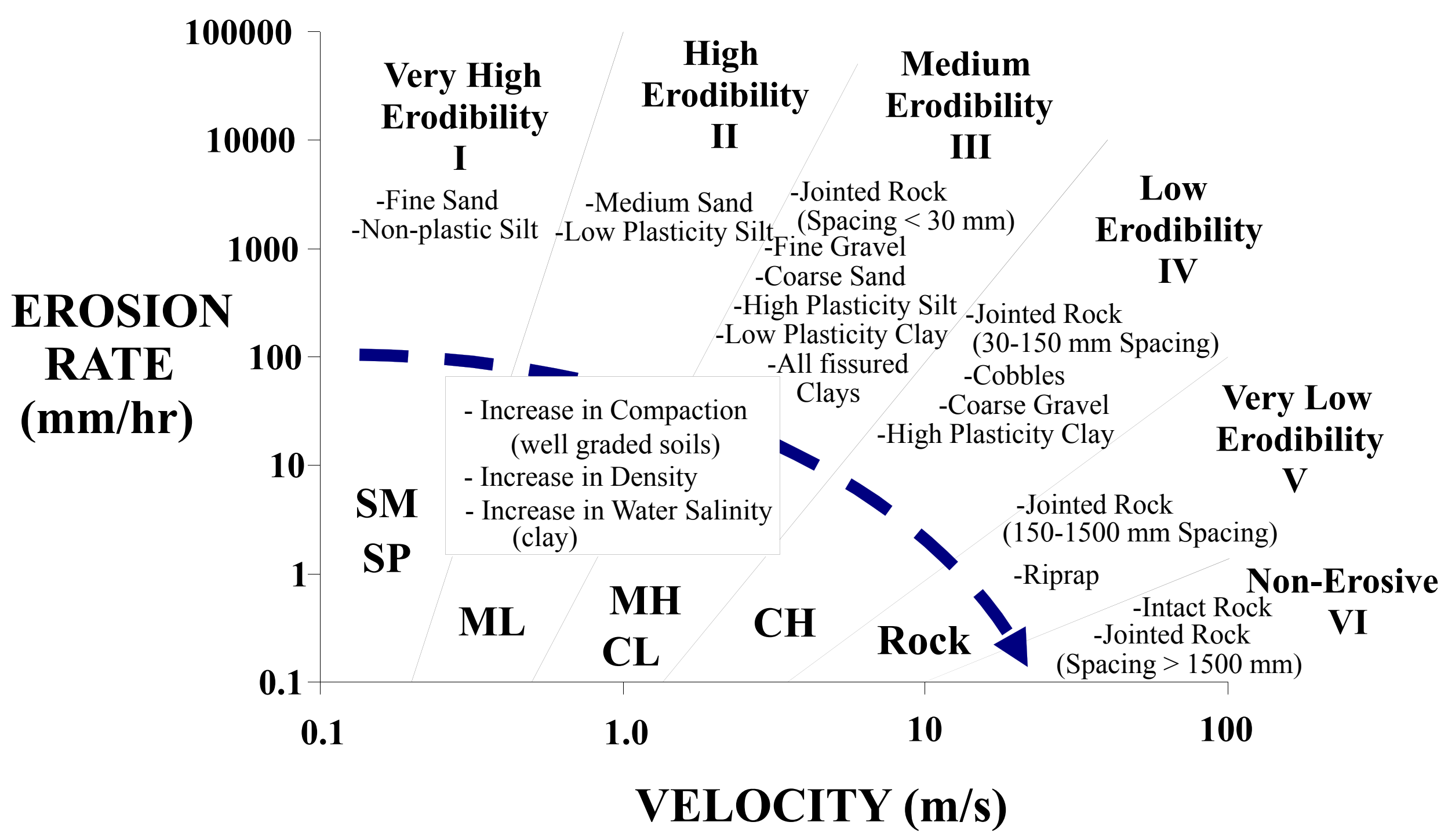

Figure 7 - Soil erosion chart (Briaud 2013) 


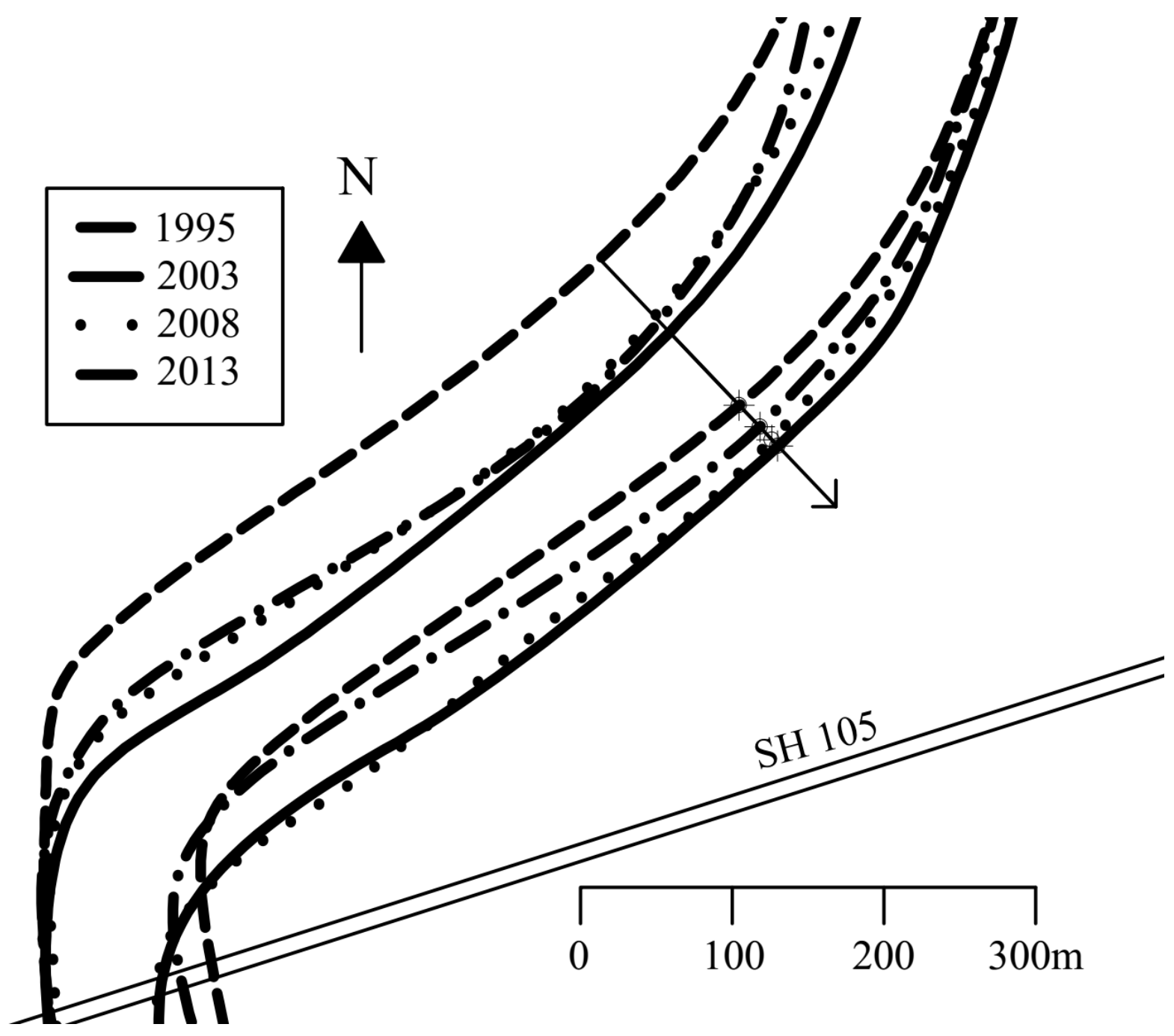

Fig. 8 - Migration of the Brazos River meander from 1995 to 2013. 


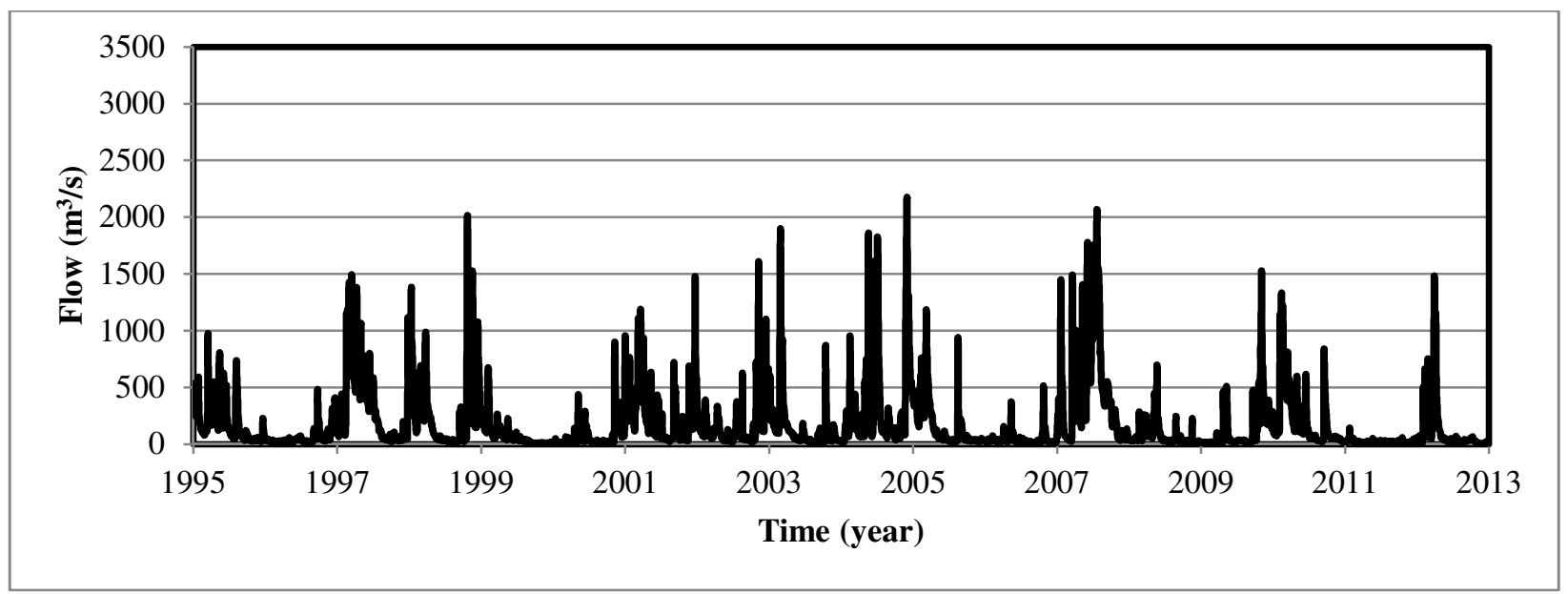

Fig. 9 - Flow hydrograph for the Brazos River at the meander location from 1960 to 2013 (USGS gage station 8111500). 


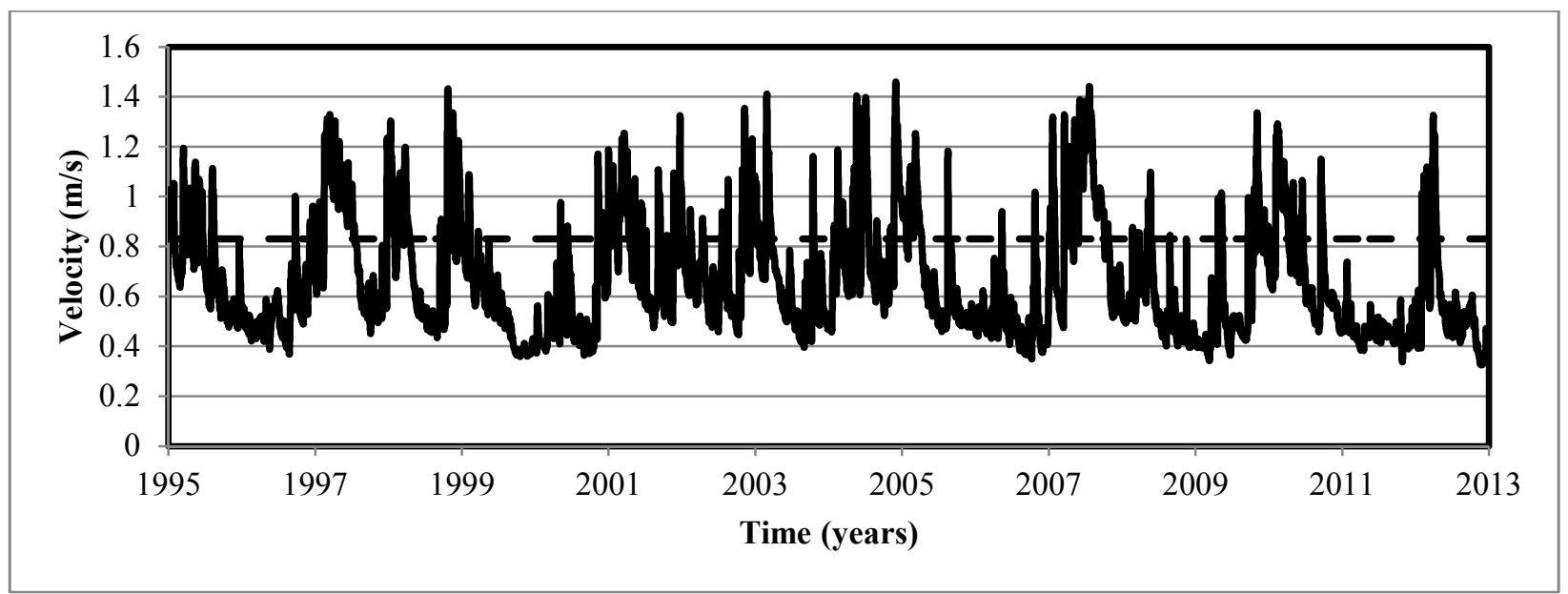

Fig. 10 - Velocity hydrograph for the Brazos River at the meander location from 1960 to 2013 (USGS gage station 8111500). 


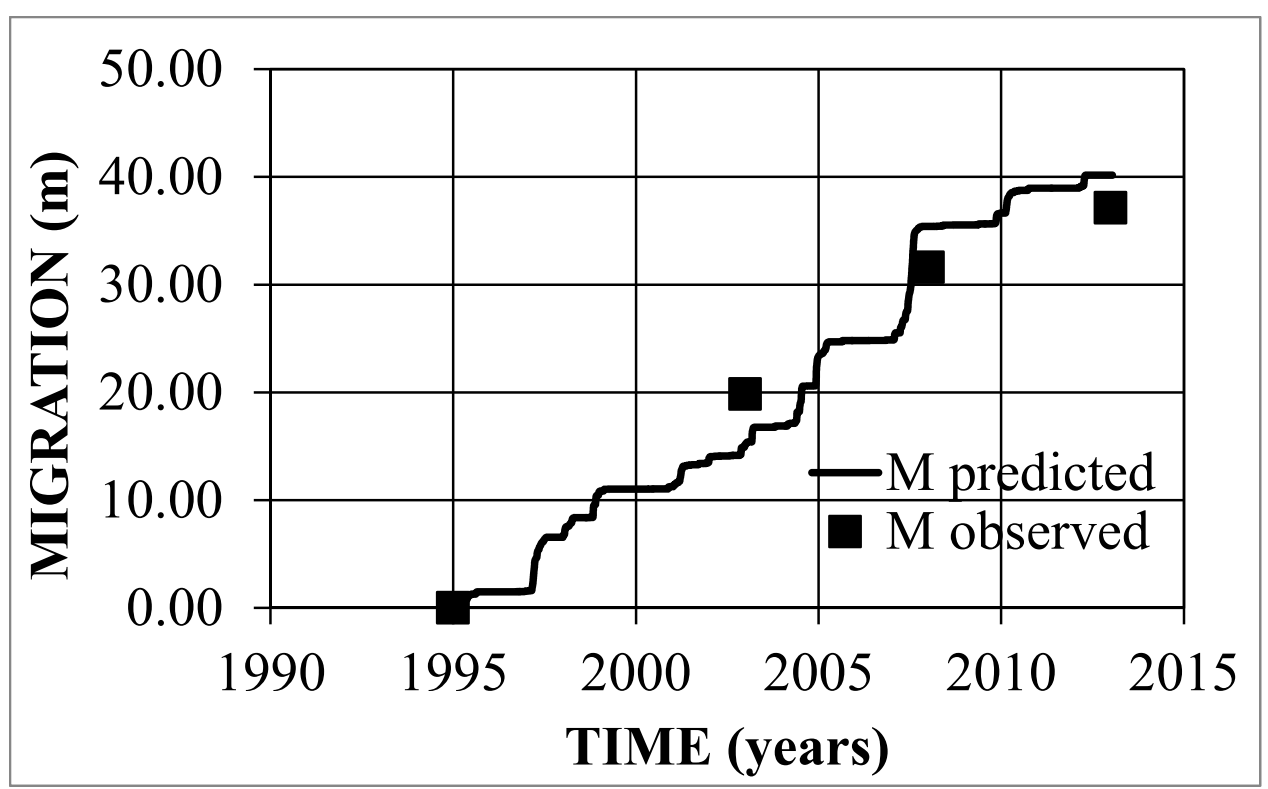

Fig. 11 - Meander migration of the Brazos River meander from 1995 to 2013. 


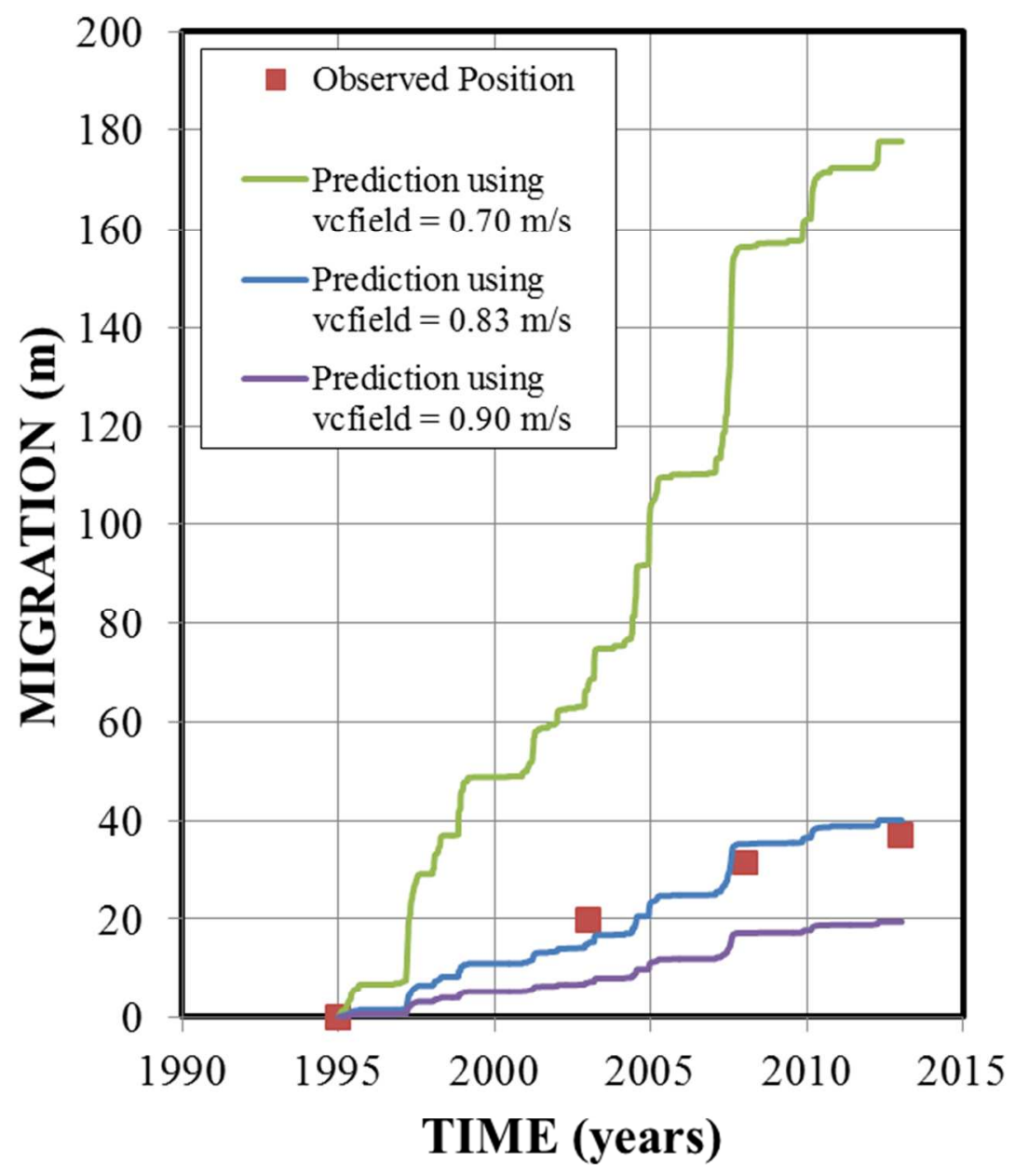

Fig. 12 - Sensitivity of meander migration prediction to the critical velocity. 


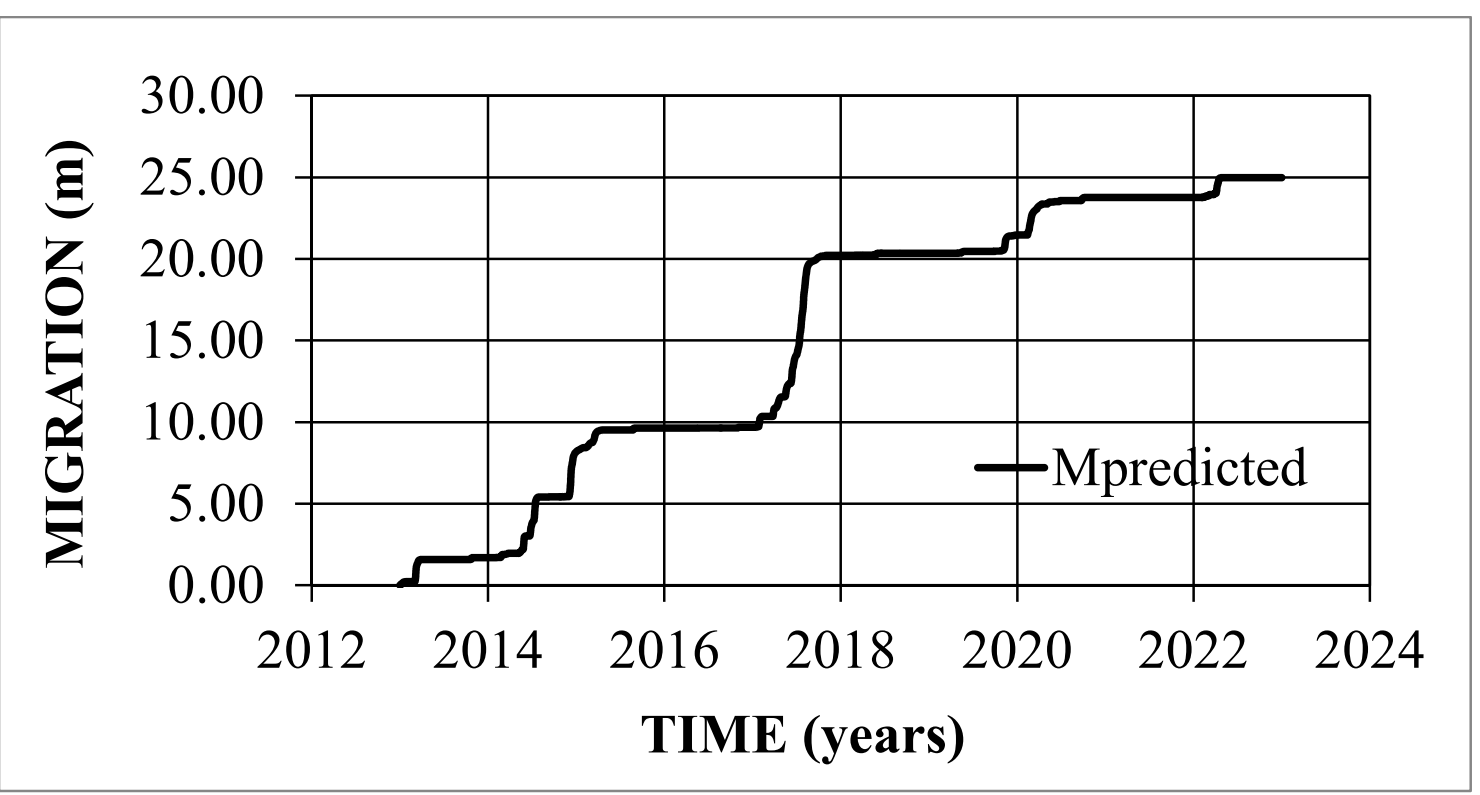

Fig. 13 - Predicted future meander migration. 

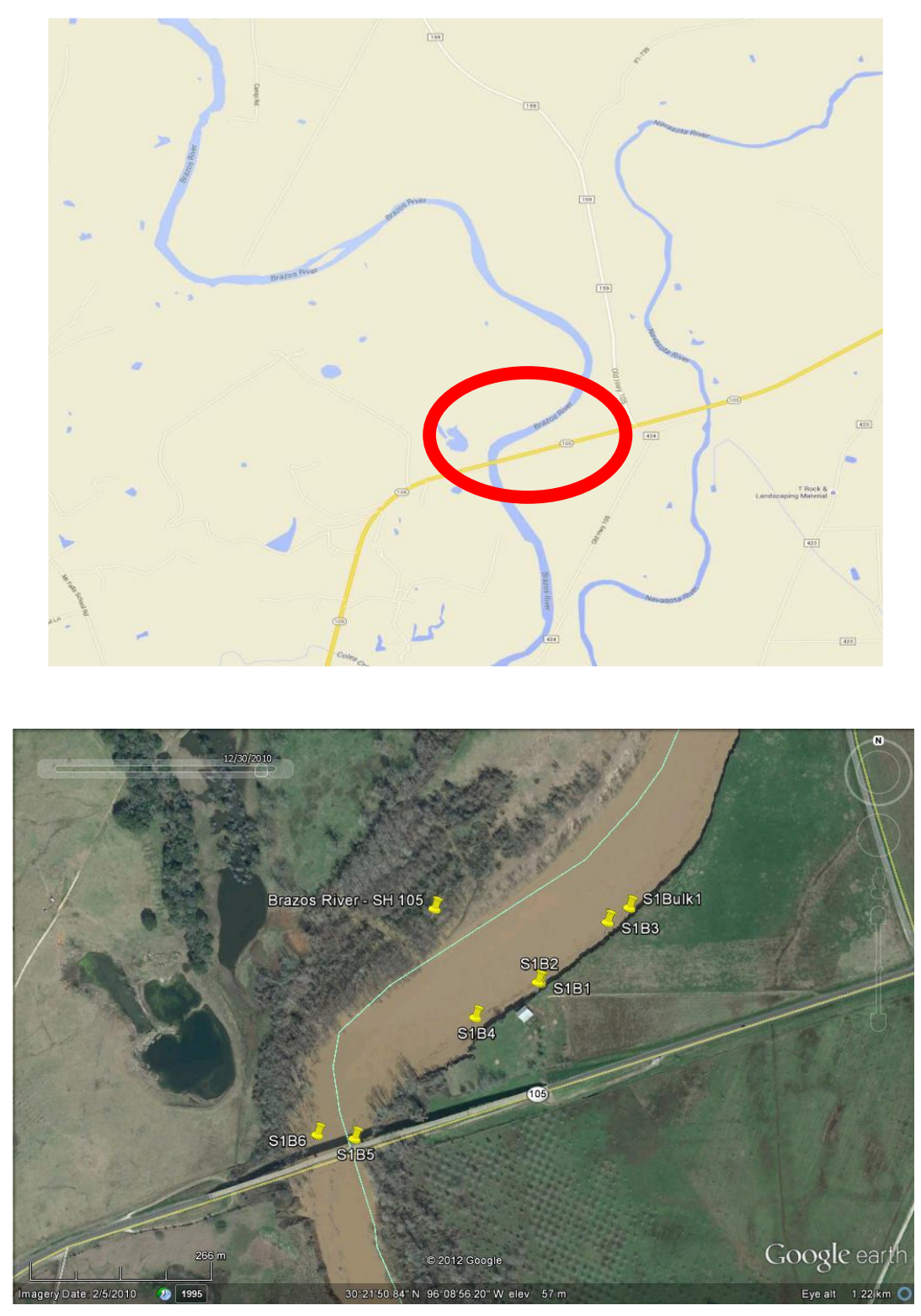

Fig. 14 - Brazos River meander and sample locations (Courtesy of Google Maps): (a) map, (b) Aerial photo. 


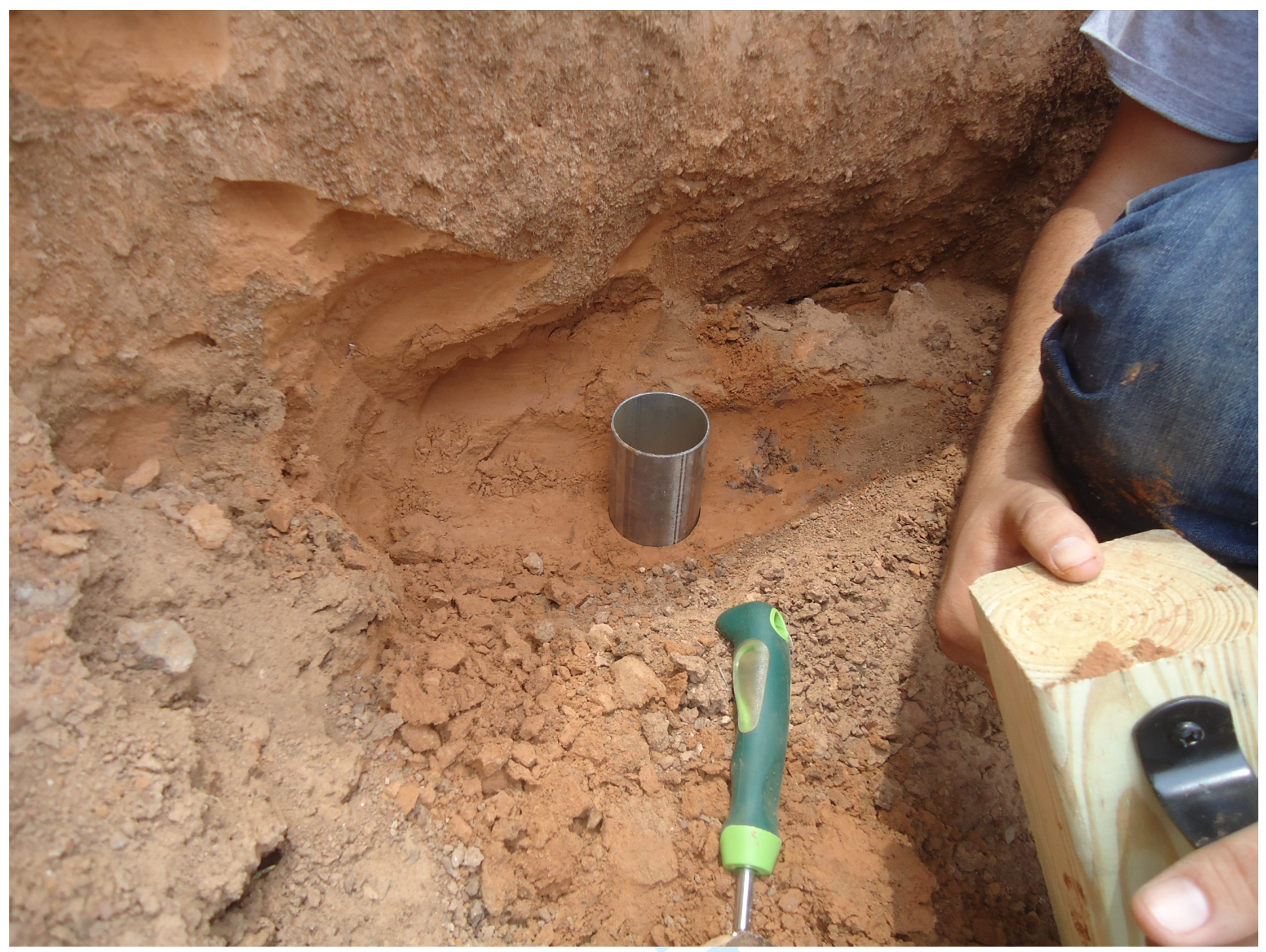

Fig. 15 - Collecting samples from the bank 
(a)

(b)
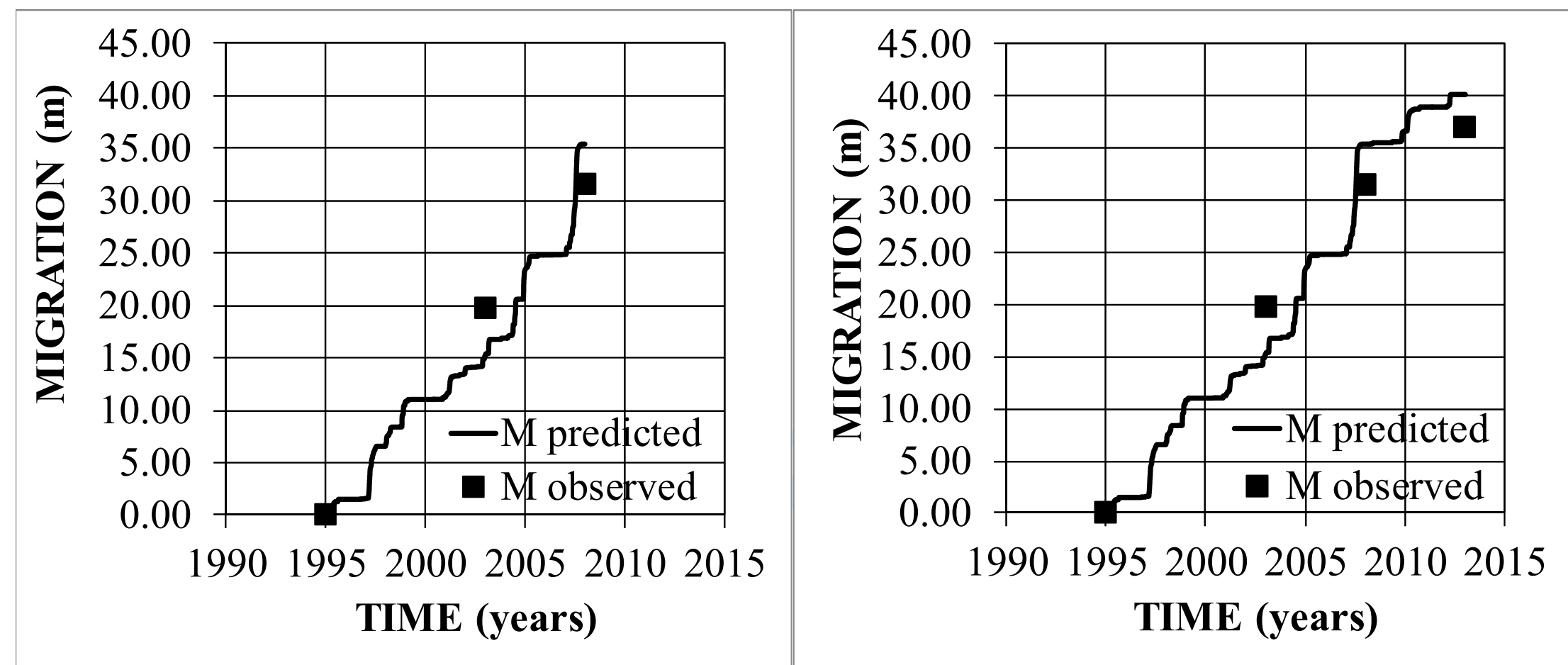

Fig. 17 - Brazos River verification of prediction with field critical velocity of $0.83 \mathrm{~m} / \mathrm{s}$. (a) first matching period, (b) second prediction period. 
(a)

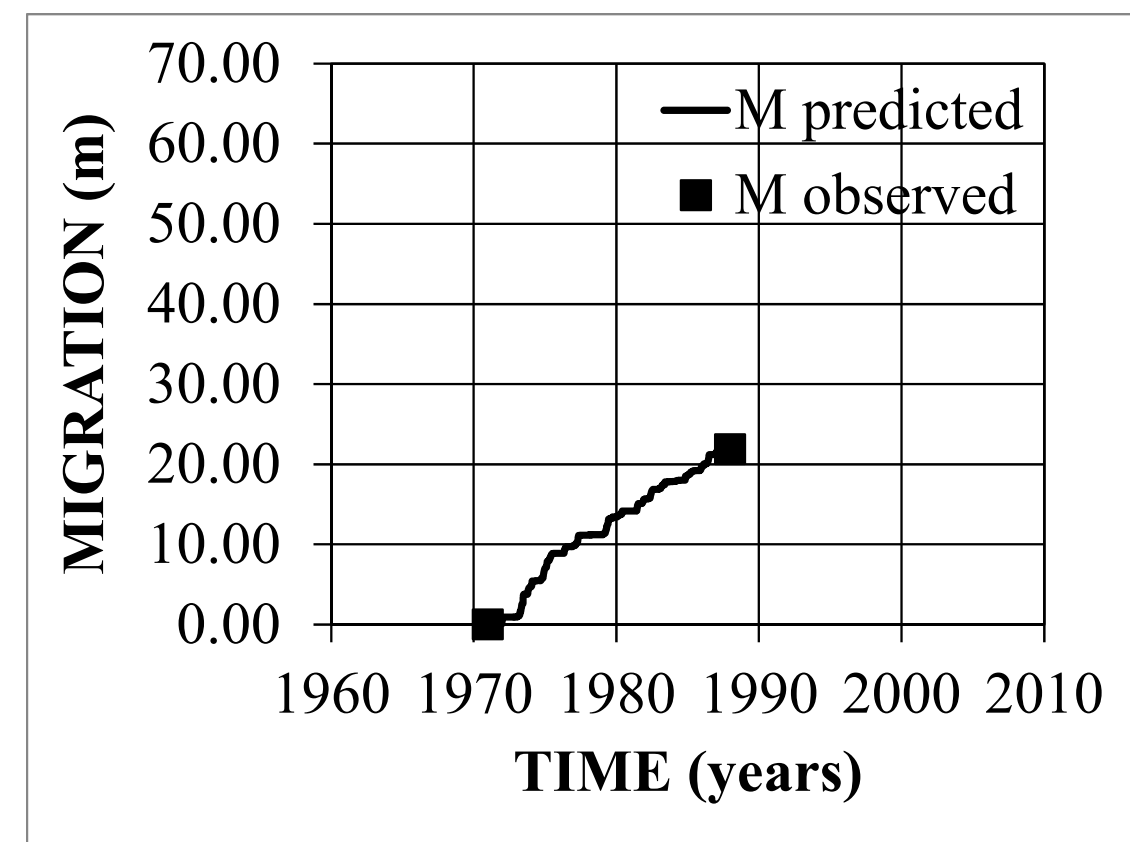

(b)

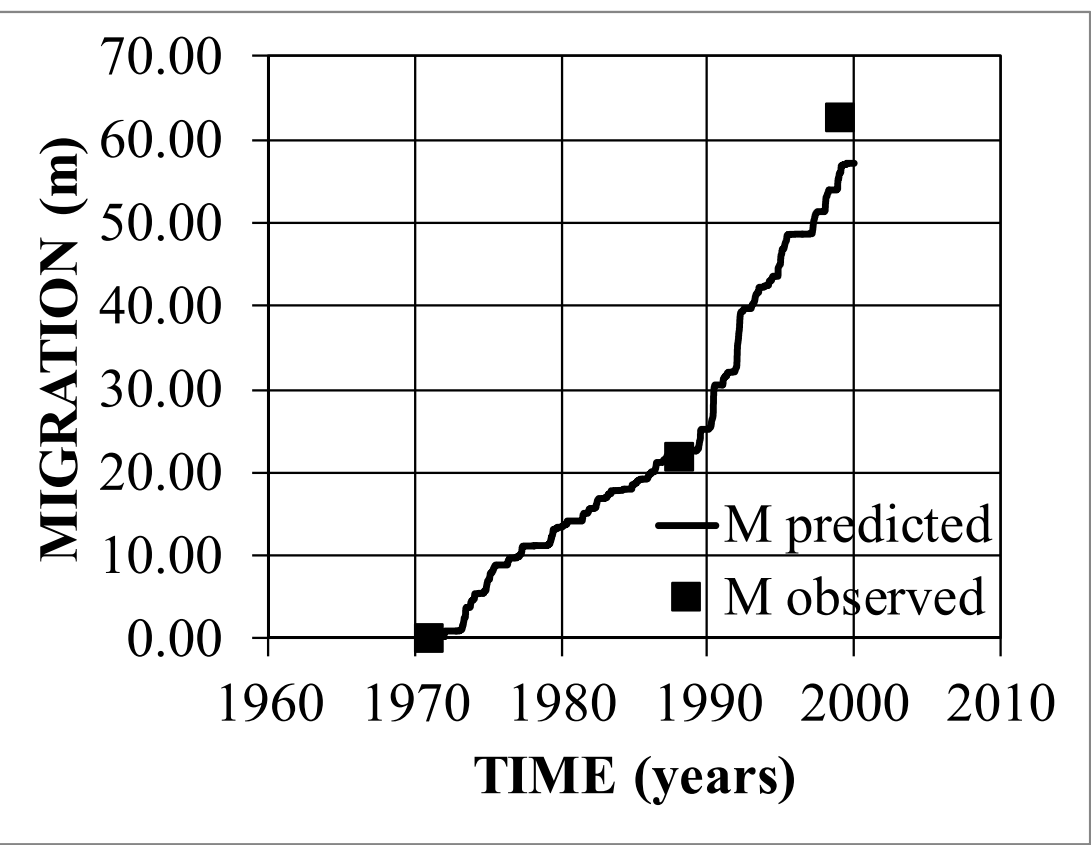

Fig. 18 - Trinity River verification of prediction with field critical velocity of $0.77 \mathrm{~m} / \mathrm{s}$. (a) first matching period, (b) second prediction period. 
(a)

(b)

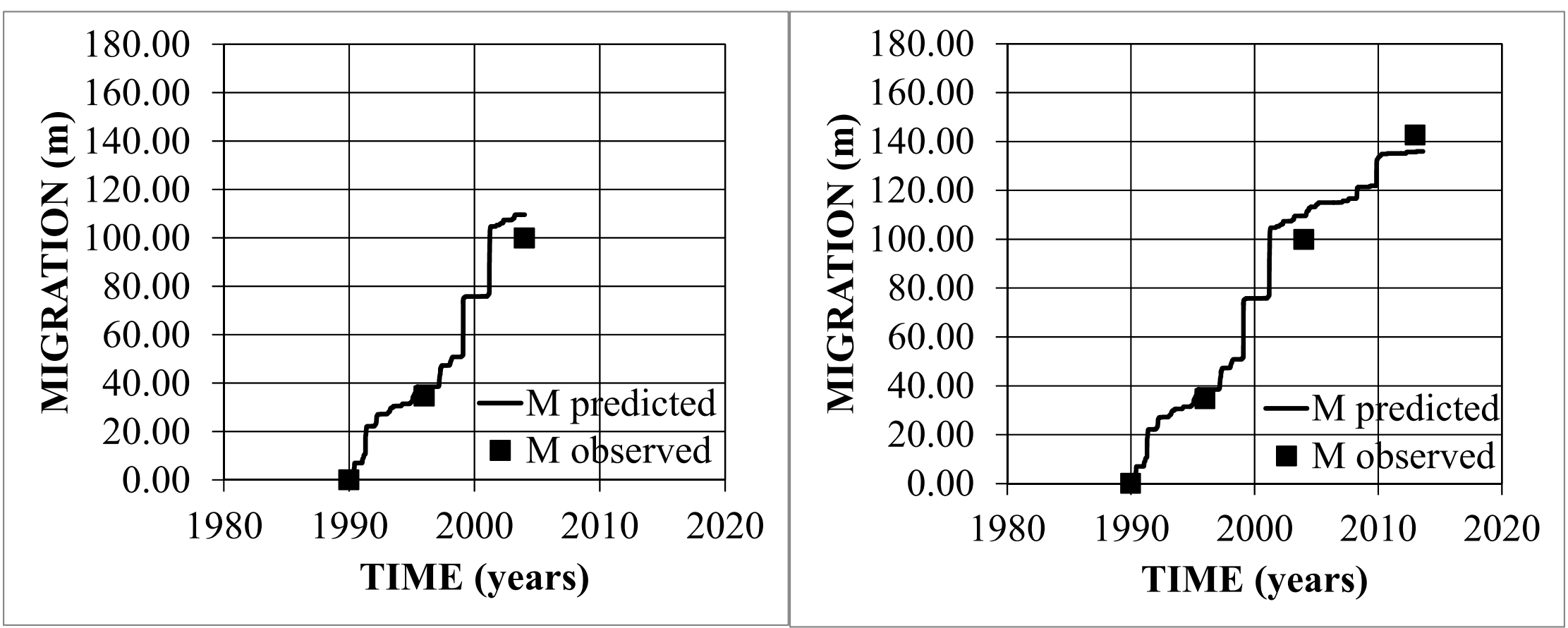

Fig. 19 - Sabine River verification of prediction with field critical velocity of $0.91 \mathrm{~m} / \mathrm{s}$. (a) first matching period, (b) second prediction period. 
(a)

(b)

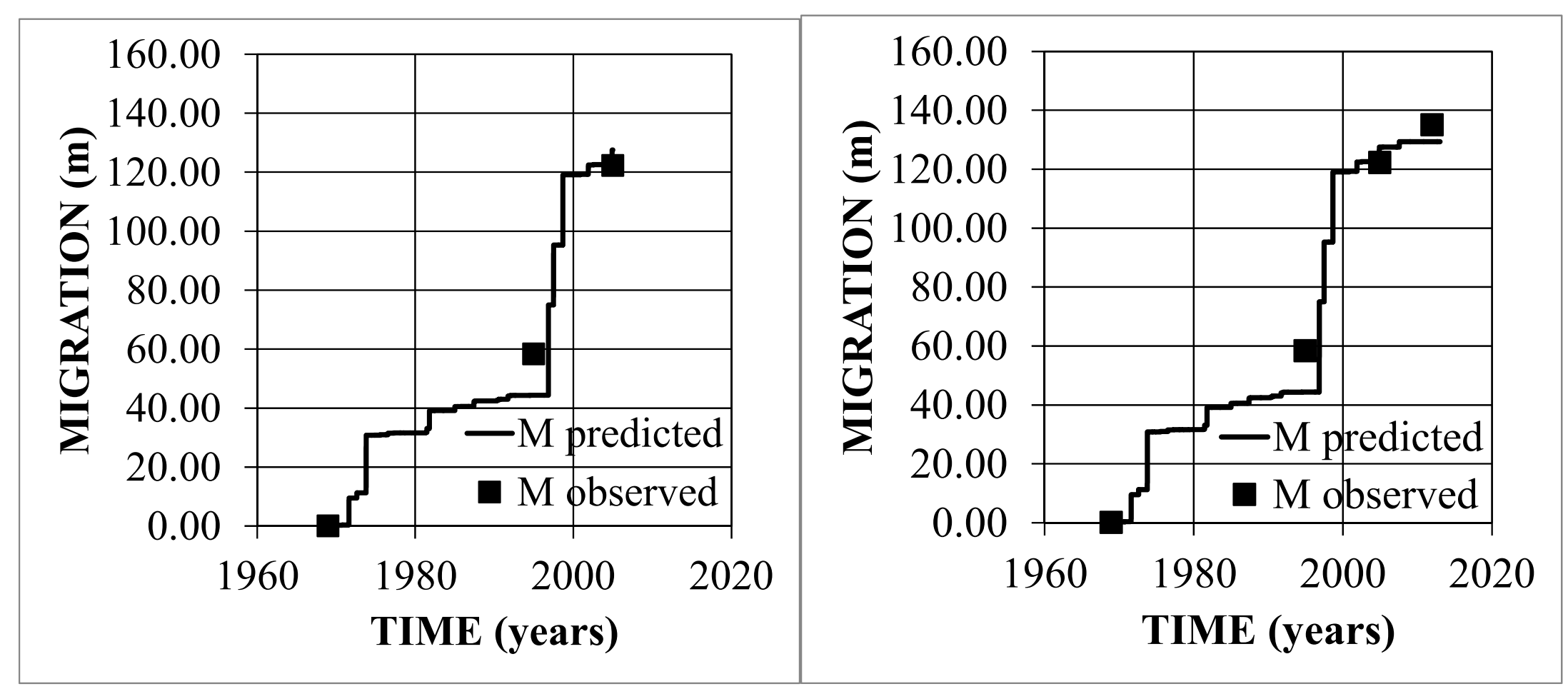

Fig. 20 - Nueces River verification of prediction with field critical velocity of $0.54 \mathrm{~m} / \mathrm{s}$. (a) first matching period, (b) second prediction period. 
(a)

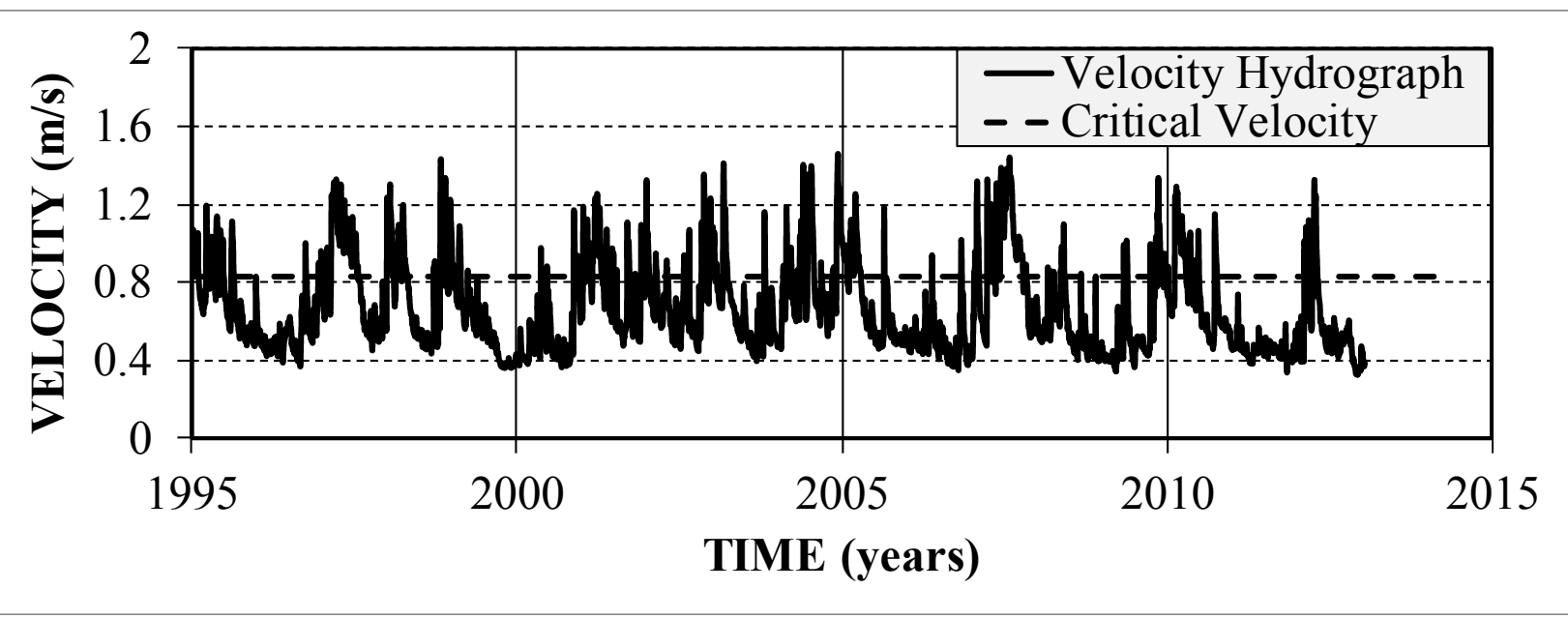

(b)

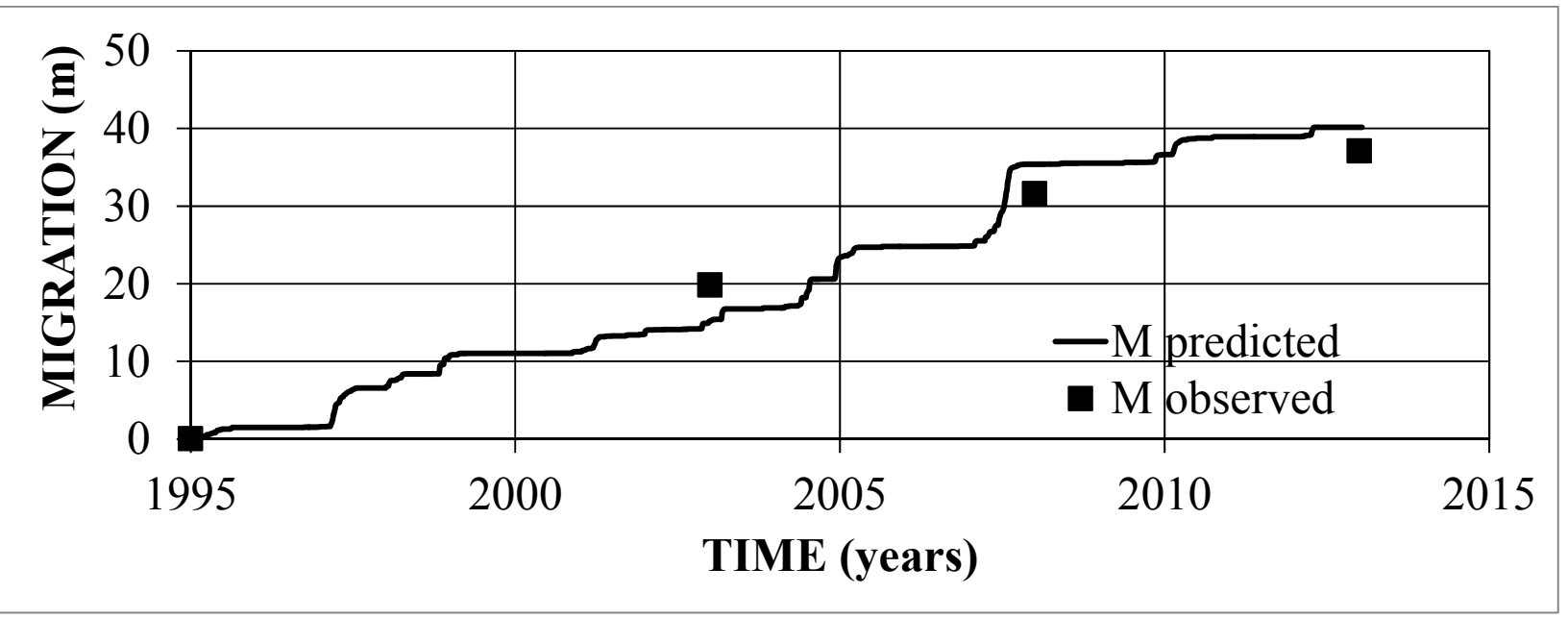

Fig. 21 - Velocity hydrograph and corresponding meander migration for the Brazos River (critical field velocity $=0.83 \mathrm{~m} / \mathrm{s}$ ) 
a)

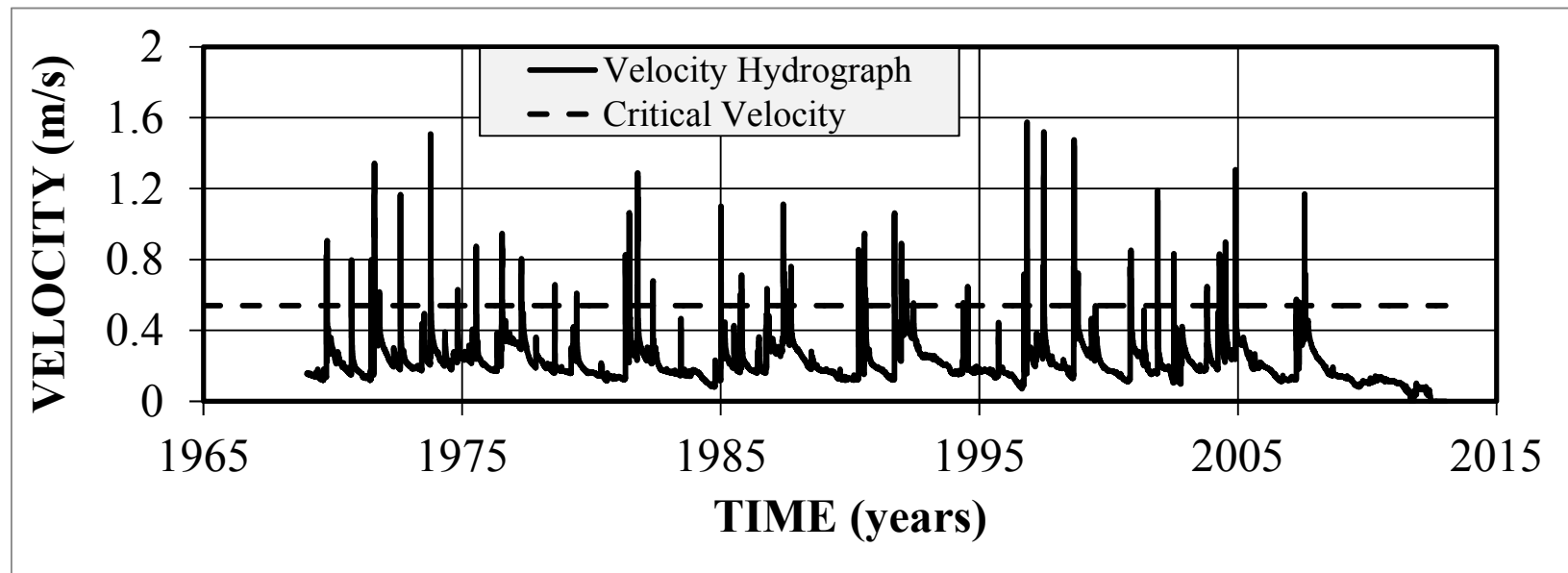

b)

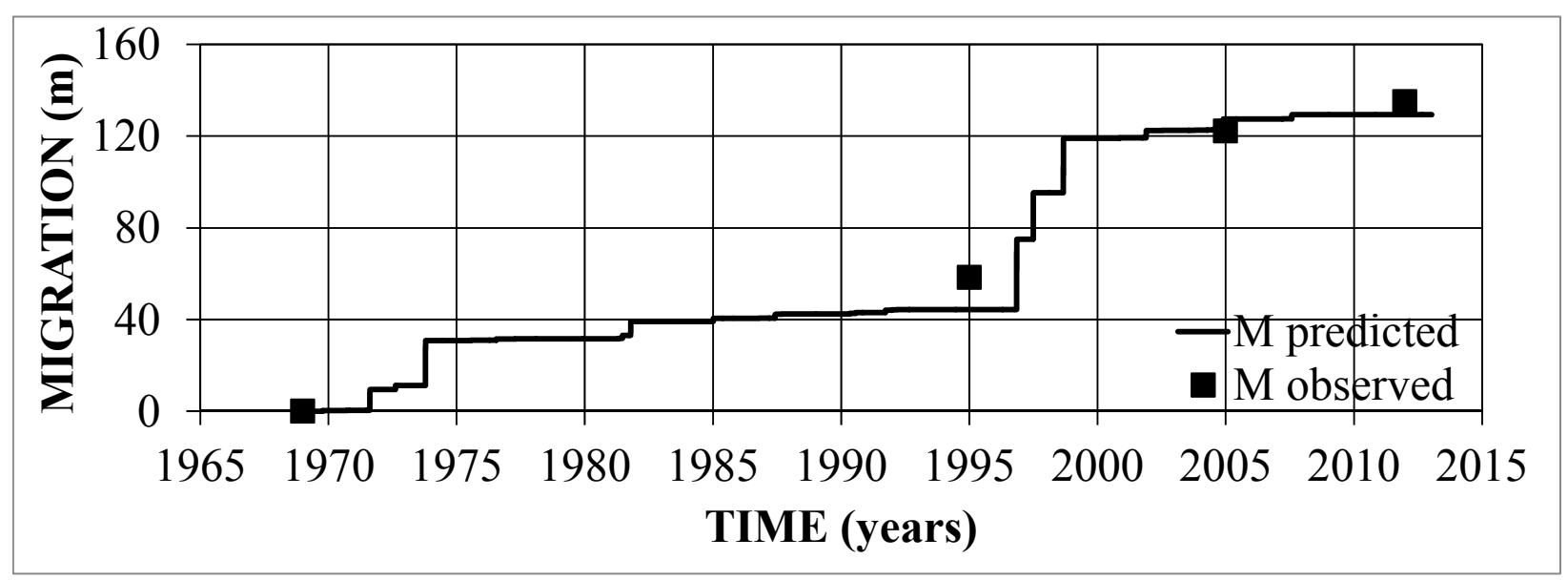

Fig. 22 - Velocity hydrograph and corresponding meander migration for the Nueces River (critical field velocity $=0.54 \mathrm{~m} / \mathrm{s}$ ) 


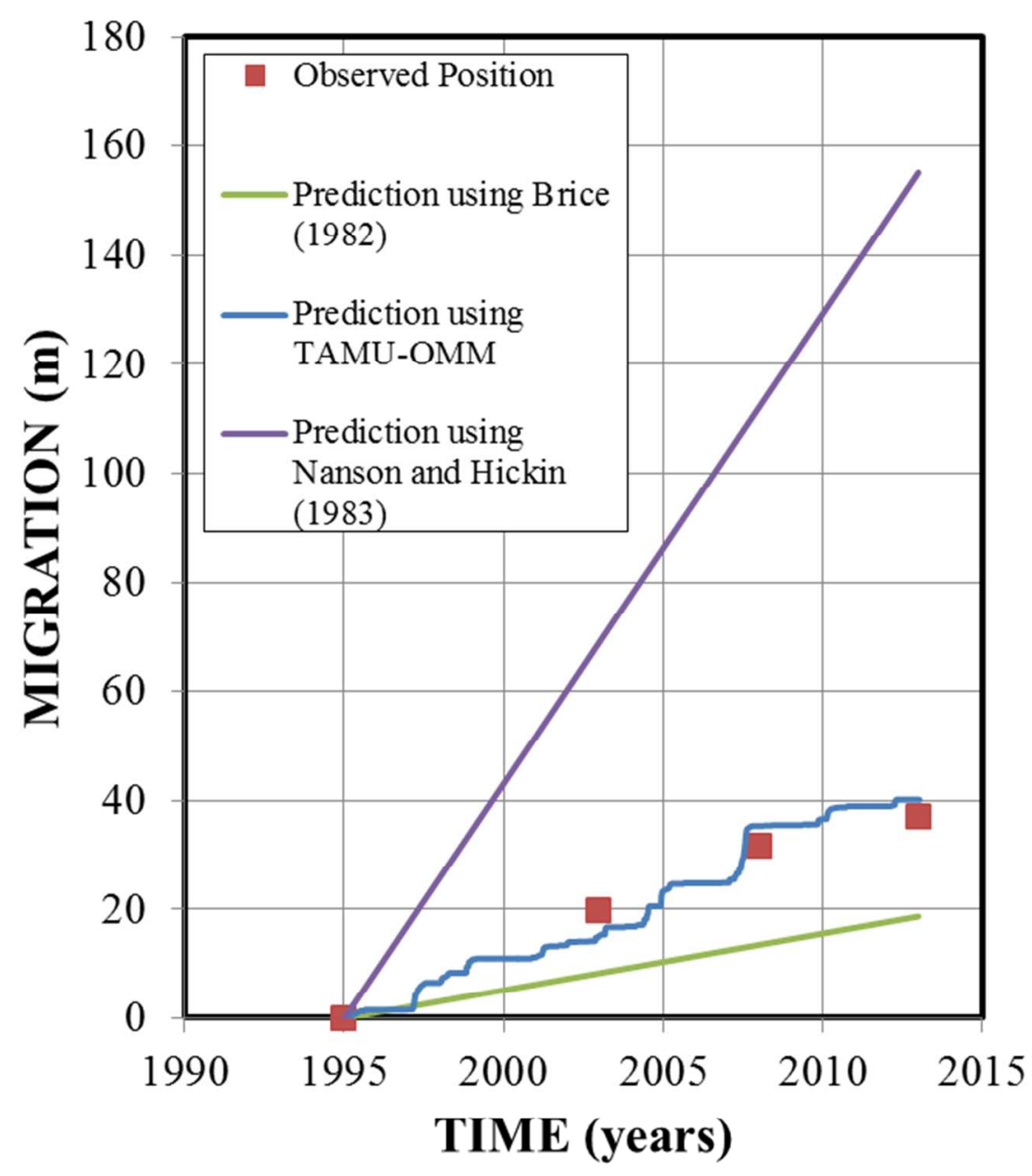

Fig. 23 - Comparison between the prediction by TAMU-OMM, Brice (1982) and Nanson and Hickin (1983). 